National Marine

Fisheries Service

NOAA
Fishery Bulletin

ar established in 1881 o
Spencer F. Baird

First U.S. Commissione

of Fisheries and founder of Fishery Bulletin
Abstract-One of the major challenges in trophic ecology is to understand how organisms interact with each other and to apply this knowledge to the management of populations, communities and ecosystems. Our goal was to examine fine-scale variability in the feeding habits and trophic position of yellowfin tuna (Thunnus albacares) and skipjack tuna (Katsuwonus pelamis) caught together in mixed schools by purse seine to examine the null hypothesis that the association between these 2 tuna species is not related to trophic interactions. In total, 439 yellowfin tuna and 216 skipjack tuna were collected in 3 different areas in the eastern tropical Pacific Ocean during 2005. The stomachs of both tuna species contained prey at different stages of digestion, which indicated intermittent feeding throughout the course of the day. Yellowfin tuna consumed mainly epipelagic crustaceans and mesopelagic squids, whereas epipelagic euphausiids and epipelagic flyingfish were the most abundant prey species in the stomach contents of skipjack tuna. Our results suggested that both tuna species employed an opportunistic predation strategy, but significant dietary differences showed that they occupy different trophic levels, and that there is no food competition between yellowfin and skipjack tunas in the eastern tropical Pacific Ocean.

Manuscript submitted 10 April 2016. Manuscript accepted 2 March 2017. Fish. Bull. 115:252-268 (2017). Online publication date: 28 March 2017. doi: 10.7755/FB.115.2.11.

The views and opinions expressed or implied in this article are those of the author (or authors) and do not necessarily reflect the position of the National Marine Fisheries Service, NOAA.

\title{
Trophic segregation of mixed schools of yellowfin tuna (Thunnus albacares) and skipjack tuna (Katsuwonus pelamis) caught in the eastern tropical Pacific Ocean
}

\author{
Vanessa G. Alatorre-Ramirez ${ }^{1}$ \\ Felipe Galván-Magaña (contact author) ${ }^{1}$ \\ Yassir E. Torres-Rojas ${ }^{2}$ \\ Robert J. Olson ${ }^{3}$ \\ Email address for contact author: galvan.felipe@gmail.com \\ 1 Instituto Politécnico Nacional \\ Centro Interdisciplinario de Ciencias Marinas \\ Avenida Instituto Politécnico Nacional s/n \\ Colonia Playa Palo de Santa Rita \\ 23096 La Paz, Baja California Sur, México \\ 2 Instituto de Ecología Pesquerías y Oceanografía del Golfo de México \\ Universidad Autónoma de Campeche (EPOMEX-UAC) \\ Campus 6 \\ Avenida Héroe de Nacozari 480 \\ 24029 San Francisco de Campeche, Campeche, México \\ 3 Inter-American Tropical Tuna Commission \\ 8901 La Jolla Shores Drive \\ La Jolla, California 92037-1509
}

The eastern tropical Pacific Ocean (ETPO) is one of the most productive oceanic provinces on the planet (Picaut, 1985; Fiedler et al., 1991; Pennington et al., 2006). The tuna fishery in the ETPO is one of the most important in the world; the 2012 annual catches of yellowfin tuna (Thunnus albacares) and skipjack tuna (Katsuwonus pelamis) exceeded 209,000 and 271,000 metric tons, respectively (IATTC ${ }^{1}$ ).

Yellowfin and skipjack tunas are schooling species that are frequently found together in large aggregations (Scott et al., 2012); in the ETPO they are often co-occurring and captured by purse-seine near the sea surface.

${ }^{1}$ IATTC (Inter-American Tropical Tuna Commission). 2014. Tunas and billfishes in the eastern Pacific Ocean in 2013. Inter-Am. Trop. Tuna Comm., Fish. Status Rep. 12, 177 p. [Available from website.]
Despite intensive research on these 2 tuna species, the association between them remains unexplained. The best documented and understood association between large marine organisms in the ETPO is that between yellowfin tuna and dolphins (Stuntz ${ }^{2}$; Scott and Cattanach, 1998). The tunadolphin association appears to be a strategy to reduce the risk of predation for one or both species (Scott et al., 2012).

Associations among marine organisms can result in increased feeding success of one or both of the associated species (Nikolsky, 1963). Yellowfin and skipjack tunas require large amounts of energy to sustain themselves (Olson and Boggs, 1986;

${ }^{2}$ Stuntz, W. E. 1981. The tuna-dolphin bond: a discussion of current hypotheses. NOAA Southwest Fish. Cent. Admin. Rep. LJ-81-19, 9 p. 
Korsmeyer and Dewar, 2001), and consequently previous authors have suggested that food acquisition is one factor that could explain the association of these 2 tuna species (Sund et al., 1981; Petit, 1991). The diets of yellowfin and skipjack tunas in the ETPO have been described individually (Galván-Magaña, 1988; RománReyes, 2000; Olson et al., 2014) with notable intraspecific differences related to size class and time of capture (yellowfin tuna: Olson et al., 2014; skipjack tuna: IATTC ${ }^{1}$ ). The diets of co-occurring yellowfin and skipjack tunas in the northern ETPO were evaluated by Alverson (1963), and he found only a minor diet overlap owing to the consumption of pelagic red crabs (Pleuroncodes planipes) by both species. There is, therefore, a scarcity of information regarding whether competitive trophic interactions play a role in the association between yellowfin and skipjack tunas throughout the entire ETPO. Apart from documenting diet overlap and potential competition, diet studies of predatory fishes also provide valuable information on ingested prey and their spatial and temporal variation in abundance and biomass. Understanding interactions in the food web is a prerequisite for gaining insight into the role of predators, commercial fisheries, and environmental effects on ecosystem structure and dynamics. Prey species are often the central key link in such interactions (GalvánMagaña, 1999; Olson and Watters, 2003; Griffiths et al., 2013).

The goals of our study were 1) to analyze the diets of associated yellowfin and skipjack tunas caught in the ETPO, and 2) to examine diet variability in terms of the area, season, capture time of day, and tuna size class and sex in order to assess the hypothesis that competitive trophic interactions form the basis for the association between these 2 tuna species. Our data provide important information on the feeding strategies of yellowfin and skipjack tunas on mid-trophic-level communities at various spatiotemporal scales in the pelagic ETPO.

\section{Materials and methods}

The study area was located in the ETPO between $35^{\circ}$ and $5^{\circ} \mathrm{N}$, and from $140^{\circ} \mathrm{W}$ to the coastline (Fig. 1). This area is characterized by a well-developed, relatively shallow thermocline, generally less than $100 \mathrm{~m}$ deep and is influenced by 6 major surface currents and 4 subsurface currents (Kessler, 2006). Zone 1 is influenced partially by the California Current. Zone 3 is influenced by the North Equatorial Current, and both zones 2 and 3 are influenced by the North Equatorial Counter Current, and the north and south subsurface Counter Current (Lavin et al., 1997).

Samples of yellowfin and skipjack tunas were collected simultaneously from 25 purse-seine sets during 15 trips by observers from the Inter-American Tropical Tuna Commission, between January through November 2005. In the ETPO, the tuna fleet uses 3 types of capture methods: sets associated with floating objects, sets associated with dolphins, and sets associated with free-swimming schools of tuna that are not associated with floating objects or with larger marine species. The tunas were identified, the capture location, date, time of day (morning, afternoon, or evening), fork length (FL), and sex of each specimen were recorded, and the stomach contents were collected and immediately frozen.

The stomach analyses were conducted at the Centro Interdisciplinario de Ciencias Marinas in La Paz, Mexico. In the laboratory, we thawed the stomach contents and categorized the digestive state of the prey species according to the digestive levels described by Galvan-Magaña (1988) who assigned 4 digestive levels: $1=$ food includes recently consumed items; $2=$ food items with little to no skin remaining; $3=$ presence of fish skeletons; and $4=$ presence of hard structures like fish otoliths, crustacean remains, and cephalopod beaks.

For prey items (fish, crustaceans, and cephalopods) at digestive level 1, we used identification keys by Allen and Robertson (1994), Fischer et al. (1995), and Thomson et al. (2000); whereas for prey items at digestive levels 2 and 3, we used the taxonomic key by Clothier (1950), which is based on vertebral characteristics (e.g., number, position, and form of the vertebrae). Finally, prey items at digestion level 4 were identified by using keys by Fitch and Brownell (1968) for fish species, Brusca (1980) for crustaceans, and Wolff (1984) and Clarke (1986) for cephalopods.

Once the prey items were identified, the data were stratified by area (based on Galván-Magaña, 1999), month, time of capture, sex, and size class. Size classes were divided at $85 \mathrm{~cm}$ FL for yellowfin tuna, with small defined as 1-85 cm FL and large defined as $>85 \mathrm{~cm} \mathrm{FL}$, (Schaefer, 1998); and at $50 \mathrm{~cm}$ FL for skipjack tuna, with small defined as 1-50 cm FL and large defined

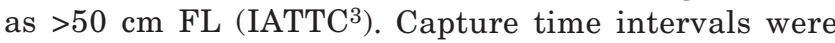
morning (0900-1059), afternoon (1100-1359), and evening (1400-1600).

We used the program EstimateS (Colwell, 2006) to construct cumulative prey curves to determine whether the number of stomachs collected were sufficient to represent the diet of both yellowfin and skipjack tunas (Ferry and Cailliet, 1996). The cumulative curves were generated by randomizing the species richness and abundance data (100 times) for the total number of stomachs to obtain cumulative Shannon-Wiener diversity values. Then, we calculated the coefficient of variation $(\mathrm{CV})$ of the diversity values as an indicator of the degree of variability of the diet. CVs $<0.05$ were considered adequate for the representation of the trophic spectrum of yellowfin and skipjack tunas (Steel and Torrie, 1992). Finally, cumulative diversity and CV values were plotted in relation to the number of stomachs analyzed.

\footnotetext{
${ }^{3}$ IATTC (Inter-American Tropical Tuna Commission). 2002. Annual report of the Inter-American Tropical Tuna Commission 2000, 171 p. IATTC, La Jolla, CA. [Available from website.]
} 


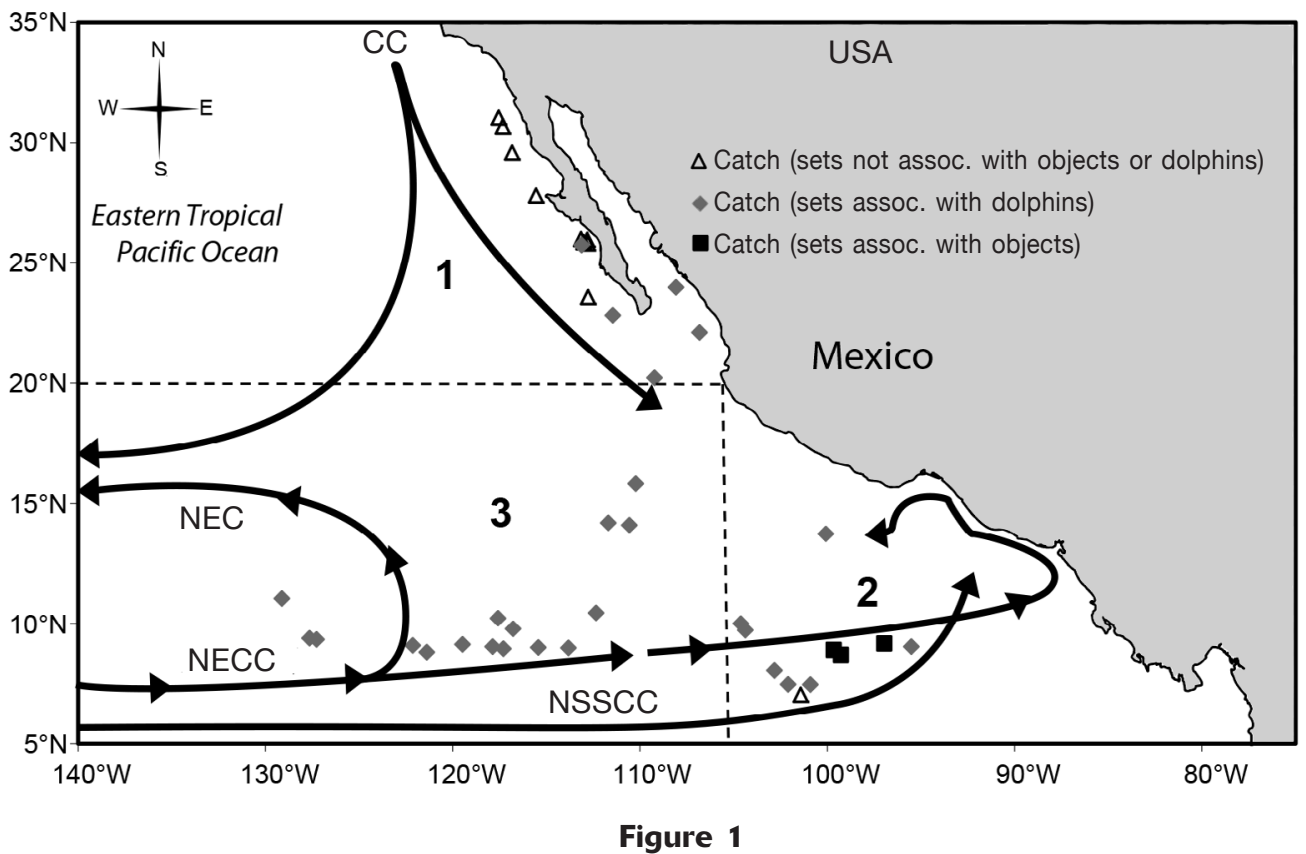

Map of zones (1,2, and 3) in the eastern tropical Pacific Ocean fished by the Mexican tuna fleet. The zones are based on trophic relationships between pelagic top predators according to Galván-Magaña (1999), and on the subsurface currents that influence the zones: California Current (CC), North Equatorial Current (NEC), North Equatorial Counter Current (NECC), North and South subsurface Counter Current (NSSCC), according to Lavin et al. (1997). Squares, triangles, and diamonds indicate locations where tunas were caught in 2005 in sets associated (assoc.) with floating objects, in sets not associated with floating objects or dolphins), and in sets associated with dolphins, respectively.

The diet data for both species were analyzed as mean proportions by number $(\% \mathrm{MN})$ and weight $(\% \mathrm{MW})$ for individual fish, then averaged for each prey type, and multiplied by 100 (Chipps and Garvey, 2007). Also, the index of relative importance index (IRI) was calculated with the formula described by Pinkas et al. (1971) and modified as a percentage (Cortés, 1997):

$$
I R I=(\% N+\% W) \times \% F O,
$$

where $\% \mathrm{~N}$ and $\% \mathrm{~W}=$ the number and wet weight of each food item as percentages, respectively; and

$\% \mathrm{FO}=$ the percentage frequency of occurrence (presence-absence) of each food item in all stomachs that contained food.

The diet breadth $\left(B_{\mathrm{i}}\right)$ of yellowfin and skipjack tunas was evaluated with the Levin's standardized index by sex, size class, month, and time interval of capture (Krebs, 1999). Index values ranged from 0 to 1 ; low values $(<0.6)$ indicated specialist diets and higher values $(\geq 0.6)$ indicated generalist diets (Labropoulou and Eleftheriou, 1997).

$$
B_{\mathrm{i}}=\frac{1}{(n-1)}\left(\frac{1}{\left(\sum_{\mathrm{ji}}^{P^{2}}\right.}-1\right),
$$

where $B_{\mathrm{i}}=$ Levin's index for predator $I$;

$\Sigma P^{2}{ }_{\mathrm{ji}}=$ the numerical proportion of the $j$ th prey item in predator $i$ 's diet; and

$n=$ the number of prey categories.

The trophic level $\left(T L_{\mathrm{i}}\right)$ of yellowfin and skipjack tunas based on stomach contents was calculated with the equation proposed by Christensen and Pauly (1992):

$$
T L_{\mathrm{i}}=1+\left(\sum_{\mathrm{j}=1}^{\mathrm{n}} D C_{\mathrm{ji}}\right)\left(T L_{\mathrm{j}}\right),
$$

where $T L_{\mathrm{i}}=$ the trophic level of predator species $i$;

$D C_{\mathrm{ji}}=$ the diet composition in weight, in terms of the prey proportion $j$ in the predator diet $i$

$T L_{\mathrm{j}}=$ the trophic level of all prey species $j$; and

$n=$ the number of prey groups in the diet.

The $T L_{\mathrm{j}}$ for fish prey species (Table 1 ) were obtained from FishBase (Froese and Pauly ${ }^{4}$, and those for cephalopods and crustaceans were obtained from Cortés (1999). We calculated the mean and standard deviation (SD) to represent the variability of the individual $T L_{\mathrm{i}}$ values.

\footnotetext{
${ }^{4}$ Froese, R., and D. Pauly (eds.). 2006. FishBase. World Wide Web electronic publication. [Available from website, accessed November 2006.]
} 


\section{Table 1}

Trophic levels of prey species $\left(\mathrm{TL}_{\mathrm{j}}\right.$ ) present in the diets of yellowfin tuna (Thunnus albacares) and skipjack tuna (Katsuwonus pelamis) caught in the eastern tropical Pacific Ocean in 2005. The values of $\mathrm{TL}_{\mathrm{j}}$ for each prey species were obtained in the references cited in the table and provided below

\begin{tabular}{|c|c|c|c|}
\hline Prey item & & $\mathrm{TL}_{\mathrm{j}}$ & References \\
\hline \multicolumn{4}{|l|}{ Cephalopoda } \\
\hline Teuthoidea & & 3.20 & Cortés, $1999^{1}$ \\
\hline Lepidoteuthidae & Pholidoteuthis boschmai & 3.20 & Cortés, $1999^{1}$ \\
\hline Loliginidae & Lolliguncula (Loliolopsis) diomedeae & 3.20 & Cortés, $1999^{1}$ \\
\hline Onychoteuthidae & Onychoteuthis banksii & 3.20 & Cortés, $1999^{1}$ \\
\hline \multirow[t]{2}{*}{ Ommastrephidae } & Dosidicus gigas & 3.20 & Cortés, $1999^{1}$ \\
\hline & Sthenoteuthis oualaniensis & 3.20 & Cortés, $1999^{1}$ \\
\hline Thysanoteuthidae & Thysanoteuthis rhombus & 3.20 & Cortés, $1999^{1}$ \\
\hline Mastigoteuthidae & Mastigoteuthis dentata & 3.20 & Cortés, $1999^{1}$ \\
\hline \multicolumn{4}{|l|}{ Octopoda } \\
\hline Bolitaenidae & Japetella diaphana & 3.20 & Cortés, $1999^{1}$ \\
\hline Argonautidae & Argonauta spp. & 3.20 & Cortés, $1999^{1}$ \\
\hline Octopodidae & Octopus rubescens & 3.20 & Cortés, $1999^{1}$ \\
\hline \multicolumn{4}{|l|}{ Crustacea } \\
\hline Squillidae & Squillid mantis shrimps & 2.52 & Cortés, $1999^{1}$ \\
\hline Euphausiidae & Nyctiphanes simplex & 2.52 & Cortés, $1999^{1}$ \\
\hline Galatheidae & Pleuroncodes planipes & 2.52 & Cortés, $1999^{1}$ \\
\hline Penaeidae & Penaeid shrimps & 2.52 & Cortés, $1999^{1}$ \\
\hline \multicolumn{4}{|l|}{ Teleostei } \\
\hline Clupeidae & Harengula thrissina & 3.10 & Whitehead and Rodriguez-Sánchez, $1995^{2}$ \\
\hline Phosichthyidae & Vinciguerria lucetia & 3.00 & Lipskaya, $1985^{3}$ \\
\hline Hemiramphidae & Oxyporhamphus micropterus & 3.10 & Lipskaya $1987^{4}$ \\
\hline \multirow{4}{*}{ Exocoetidae } & Exocoetus spp. & 3.10 & Lipskaya $1987^{4}$ \\
\hline & Exocoetus monocirrhus & 3.10 & Gorelova $1980^{5}$ \\
\hline & Exocoetus volitans & 3.10 & Lipskaya $1987^{4}$ \\
\hline & Hirundichthys spp. & 3.10 & Lipskaya $1987^{4}$ \\
\hline \multirow[t]{2}{*}{ Carangidae } & Jacks & 4.20 & Cortés $1999^{1}$ \\
\hline & Seriola lalandi & 4.10 & Craig $1960^{6}$ \\
\hline Coryphaenidae & Coryphaena hippurus & 4.50 & Palko et al. $1982^{7}$ \\
\hline Bramidae & Brama spp. & 4.40 & Watanabe et al. $2006^{8}$ \\
\hline Gempylidae & Gempylus spp. & 4.35 & Nakamura $1995^{9}$ \\
\hline Scombridae & Auxis spp. & 4.34 & Blaber et al. $1990^{10}$ \\
\hline Nomeidae & Cubiceps pauciradiatus & 3.50 & Gorelova et al. $1994^{11}$ \\
\hline Balistidae & Balistes polylepis & 3.34 & Grove and Lavenberg $1997^{12}$ \\
\hline Ostraciidae & Lactoria diaphana & 3.50 & Grove and Lavenberg $1997^{12}$ \\
\hline
\end{tabular}

${ }^{1}$ Cortés, E. 1999. Standardized diet compositions and trophic levels of sharks. ICES J. Mar. Sci. 56:707-717. Article

${ }^{2}$ Whitehead, P. J. P., and R. Rodriguez-Sanchez. 1995. Pristigasteridae. Arenquillas, sardinetas. In Guía FAO para la identificación de especies para los fines de la pesca. Pacífico centro-oriental. Volumen III. Vertebrados-parte 2 (W. Fischer, F. Krupp, W. Schneider, C. Sommer, K. E. Carpenter, and V. Niem, eds.), p. 1409-1417. FAO, Rome.

${ }^{3}$ Lipskaya, N. Y. 1985. Feeding of larvae and fry of Vinciguerria lucetia (Garman) (Gonostomatidae) in the Southeast Pacific. In Feeding and food supply of fishes at different life stages as the factor of formation of their abundance, growth and aggregations (M. I. Tarverdieva, N. Y. Lipskaya, and I. Y. Ponomarenko, eds.), p. 79-88. VNIRO, Moscow, Russia.

${ }^{4}$ Lipskaya, N.Y. 1987. Feeding of flyingfish (Exocoetidae) larvae and fingerlings in the region of the Peruvian upwelling. J. Ichthyol. 27:108-116.

${ }^{5}$ Gorelova, T. A. 1980. The feeding of young flyingfishes of the family Exocoetidae and of the smallwing flyingfish, Oxyporhamphus micropterus, of the family Hemirhamphidae. J. Ichthyol. 20:60-71.

${ }^{6}$ Craig, W. L. 1960. Food and feeding. In A study of the yellowtail Seriola dorsalis (J. L. Baxter, ed.), p. 35-46. Calif. Dep. Fish Game, Fish Bull. 110.

${ }^{7}$ Palko, B. J., G. L. Beardsley, and W. J. Richards. 1982. Synopsis of the biological data on dolphin-fishes, Coryphaena hippurus Linnaeus and Coryphaena equiselis Linnaeus. NOAA Tech. Rep. NMFS Circ. 443, 28 p.

${ }^{8}$ Watanabe, H., T. Kubodera, and S. Kawahara. 2006. Summer feeding habits of the Pacific pomfret Brama japonica in the transitional and subarctic waters of the central North Pacific. J. Fish Biol. 68:1436-1450 Article

${ }^{9}$ Nakamura, I. 1995. Gempylidae. Escolares. In Guía FAO para la identificación de especies para los fines de la pesca. Pacífico centro-oriental. Vol. II. Vertebrados-parte 1 (W. Fischer, F. Krupp, W. Schneider, C. Sommer, K. E. Carpenter, and V. Niem, eds.), p. 1106-1113. FAO, Rome.

${ }^{10}$ Blaber, S. J. M., D. A. Milton, N. J. F. Rawlinson, G. Tiroba, and P. V. Nichols. 1990. Diets of lagoon fishes of the Solomon Islands: predators of tuna baitfish and trophic effects of baitfishing on the subsistence fishery. Fish. Res. 8:263-286. Article

${ }^{11}$ Gorelova, T. A., T. B. Agafonova, and N. Y. Lipskaya. 1994. Feeding of cigarfishes (Genus Cubiceps, Stromateoidei). J. Ichthyol. 34:70-82.

${ }^{12}$ Grove, J. S., and R. J. Lavenberg. 1997. The fishes of the Galápagos Islands, 863 p. Stanford Univ. Press, Stanford, CA. 


\section{Table 2}

Fork lengths, measured in centimeters, of yellowfin tuna (Thunnus albacares) and skipjack tuna (Katsuwonus pelamis) caught in mixed schools in the eastern tropical Pacific Ocean in 2005, with standard deviations (SDs) given in parentheses after the means. No.=number of samples.

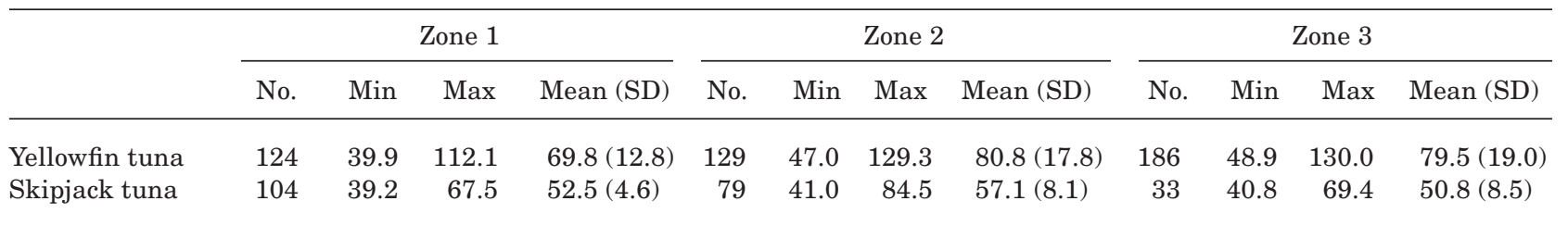

An analysis of similarities (ANOSIM) and the similarity percentage (SIMPER) analysis were carried out to evaluate the differences in diet within and between each tuna species and to establish the contribution of each prey item, respectively, with PRIMER, vers. 6.1.6 (PRIMER-E, Auckland, New Zealand). For both analyses, we used permutation-randomization methods based on the Bray-Curtis measure of similarity, also termed "the percentage difference," which is related to the mean character difference (Clarke and Warwick, 2001). The Bray-Curtis method operates at the species level, and therefore the mean similarity between groups (e.g., between males and females) can be obtained for each tuna species.

Results from ANOSIM are represented on an $R$ scale from +1 to -1 . An $R$ value of +1 indicates that all the most similar samples are within the same groups. An $\mathrm{R}$ value of 0 occurs if the high and low similarities are perfectly mixed and bear no relationship to the group and indicate a completely random distribution within the group. An $R$ value of -1 indicates that the most similar samples are all outside of the groups. Values from ANOSIM between 0.2 and 1 with significance set at $P<0.05$ indicate that the null hypothesis can be rejected and the tuna species would have significantly different diets (Clarke and Warwick, 2001). The SIMPER analysis breaks down the percentage contribution of each species to the observed similarity (or dissimilarity) between samples. Diet comparisons between yellowfin tuna and skipjack tuna were evaluated by comparing individuals captured in the same set within each area.

\section{Results}

\section{Cumulative curves for size classes and prey species}

We sampled 439 yellowfin tuna and 216 skipjack tuna from mixed schools. Yellowfin tuna were the largest (mean FL) in zone 2 and the smallest in zone 1 . Skipjack tuna were similar in mean FL in all 3 zones (Table 2). For all the yellowfin tuna samples, 381 stomachs $(87 \%)$ contained food, and 58 (13\%) were empty; whereas, for all the skipjack tuna samples, 109 stom- achs $(51 \%)$ contained food, and 107 (49\%) were empty (Table 3).

Out of a total of 25 sets, yellowfin tuna occurred in all sets and skipjack tuna occurred in only 8 sets. For yellowfin tuna, 124 stomachs with food were obtained from 9 sets in zone 1, 91 were obtained from 7 sets in zone 2, and 166 were obtained from 9 sets in zone 3. For skipjack tuna, 75 stomachs with food were obtained from 5 sets in zone 1, 22 were obtained from 2 sets in zone 2 , and 12 were obtained from 1 set in zone 3. Cumulative curves for the prey species for each zone showed that a sufficient number of stomachs were analyzed to characterize the diet of both species (Fig. $2)$, with the CVs $<0.05$ in all areas.

\section{Digestive state of prey species}

The state of digestion of the prey of both yellowfin and skipjack tunas varied widely in each sample zone. In zone 1 , both tuna species had the highest number of prey species in digestive level 2 . In zone 2 , prey species in digestion level 4 were the most common whereas in zone 3 , prey species were most often at digestive level 3 (Table 4).

\section{Diet composition in zone 1}

Yellowfin tuna prey items comprised 21 taxa (9 cephalopods, 2 crustaceans, and 10 fish species). The \% MN and $\% \mathrm{MW}$ indices indicated that the most important prey items were the pelagic red crab $(48.9 \% ; 54.2 \%)$, the jumbo squid (Dosidicus gigas) $(20.7 \% ; 16.6 \%)$, and the bigeye cigarfish (Cubiceps pauciradiatus) (13.4\%; $13.9 \%)$, respectively. According to the IRI, pelagic red crab $(61.1 \%)$ and jumbo squid $(28.7 \%)$ were the most important components in the diet (Table 5). The diversity index was 1.4 and $B_{\mathrm{i}}$ was 0.1 . The trophic level of the stomach contents was estimated at 3.9 (SD 0.4). The ANOSIM test indicated a similar diet composition by sex $(R=0.009)$, and differences among size classes ( $R=0.300, P=0.04$; small individuals primarily consumed jumbo squid and pelagic red crabs; whereas large individuals primarily consumed Cubiceps spp.), months $(R=0.360, P=0.01$; in February individuals primarily consumed Cubiceps spp., jumbo squid, and 


\begin{tabular}{|c|c|c|c|c|c|}
\hline \multicolumn{6}{|c|}{ Table 3} \\
\hline \multicolumn{6}{|c|}{$\begin{array}{l}\text { Summary description of samples of yellowfin tuna (Thunnus albacares) and skipjack tuna (Katsuwonus } \\
\text { pelamis) caught in } 2005 \text { in the eastern tropical Pacific Ocean and used for stomach contents analyses. } \\
\text { The size classes for yellowfin tuna were small (S), } 1-85 \mathrm{~cm} \text { in fork length (FL), and large (L), >85 cm } \\
\text { FL. The size classes for skipjack tuna were small (S) } 1-50 \mathrm{~cm} \text { FL, and large (L), } 50 \mathrm{~cm} \text { FL). Capture } \\
\text { times were morning }(0900-1059 \mathrm{~h}) \text {, afternoon }(1100-1359 \mathrm{~h}) \text {, and evening }(1500-1600 \mathrm{~h}) \text {. TS=total } \\
\text { stomachs; SWC=stomachs with content; n/d=no data. }\end{array}$} \\
\hline \multirow[b]{2}{*}{ Species } & \multirow[b]{2}{*}{ Category } & \multirow[b]{2}{*}{ Group } & \multicolumn{3}{|c|}{ Number of samples } \\
\hline & & & $\begin{array}{c}\text { Zone } 1 \\
\text { TS (SWC) }\end{array}$ & $\begin{array}{c}\text { Zone } 2 \\
\text { TS (SWC) }\end{array}$ & $\begin{array}{c}\text { Zone } 3 \\
\text { TS (SWC) }\end{array}$ \\
\hline \multirow{13}{*}{ Thunnus albacares } & Males & $\mathrm{S}$ & $64(64)$ & $45(30)$ & $58(52)$ \\
\hline & & $\mathrm{L}$ & $6(6)$ & $15(12)$ & $24(21)$ \\
\hline & Females & $\mathrm{S}$ & $48(48)$ & $50(33)$ & $71(63)$ \\
\hline & & $\mathrm{L}$ & $6(6)$ & $19(16)$ & $33(30)$ \\
\hline & Month & Jan. & $\mathrm{n} / \mathrm{d}$ & $89(51)$ & $\mathrm{n} / \mathrm{d}$ \\
\hline & & Feb. & $40(40)$ & $25(25)$ & $40(37)$ \\
\hline & & Aug. & $45(45)$ & $\mathrm{n} / \mathrm{d}$ & $\mathrm{n} / \mathrm{d}$ \\
\hline & & Sep. & $24(24)$ & $\mathrm{n} / \mathrm{d}$ & $20(19)$ \\
\hline & & Oct. & $\mathrm{n} / \mathrm{d}$ & $15(15)$ & $126(110)$ \\
\hline & & Nov. & $15(15)$ & $\mathrm{n} / \mathrm{d}$ & $\mathrm{n} / \mathrm{d}$ \\
\hline & Capture time & Morning & $22(22)$ & $24(20)$ & $60(55)$ \\
\hline & & Afternoon & $55(55)$ & $30(28)$ & $49(45)$ \\
\hline & & Evening & $47(47)$ & $75(43)$ & $77(66)$ \\
\hline \multirow[t]{13}{*}{ Katsuwonus pelamis } & Males & $\mathrm{S}$ & $1(1)$ & $4(4)$ & $7(3)$ \\
\hline & & $\mathrm{L}$ & $43(29)$ & $34(6)$ & $9(3)$ \\
\hline & Females & $\mathrm{S}$ & $12(10)$ & $6(5)$ & $10(4)$ \\
\hline & & $\mathrm{L}$ & $48(35)$ & $35(7)$ & $7(2)$ \\
\hline & Month & Jan. & $\mathrm{n} / \mathrm{d}$ & $30(10)$ & $\mathrm{n} / \mathrm{d}$ \\
\hline & & Feb. & $\mathrm{n} / \mathrm{d}$ & $49(12)$ & $19(5)$ \\
\hline & & Aug. & $94(65)$ & $\mathrm{n} / \mathrm{d}$ & $\mathrm{n} / \mathrm{d}$ \\
\hline & & Sep. & $\mathrm{n} / \mathrm{d}$ & $\mathrm{n} / \mathrm{d}$ & $3(3)$ \\
\hline & & Oct. & $10(10)$ & $\mathrm{n} / \mathrm{d}$ & $11(4)$ \\
\hline & & Nov. & $\mathrm{n} / \mathrm{d}$ & $\mathrm{n} / \mathrm{d}$ & $\mathrm{n} / \mathrm{d}$ \\
\hline & Capture time & Morning & $25(20)$ & $30(8)$ & $4(3)$ \\
\hline & & Afternoon & $54(35)$ & $15(6)$ & $6(3)$ \\
\hline & & Evening & $25(20)$ & $34(10)$ & $23(6)$ \\
\hline
\end{tabular}

pelagic red crab, in August they primarily consumed jumbo squid and pelagic red crab, in September they primarily consumed pelagic red crab and Auxis spp., in November they primarily consumed the Panama lightfish [Vinciguerria lucetia]), and capture times $(R=0.310, P=0.01$; in the morning individuals primarily consumed Cubiceps spp., in the afternoon they primarily consumed jumbo squid and pelagic red crab, and in the evening they primarily consumed Panama lightfish, jumbo squid, and pelagic red crab) (Fig. 3).

Skipjack tuna prey items comprised 5 taxa (2 cephalopods, 2 crustaceans and 1 fish species). The $\% \mathrm{MN}$ and $\% \mathrm{MW}$ indices indicated that the most important prey items were a krill species, Nyctiphanes simplex $(60.0 \% ; 60.0 \%)$, pelagic red crab $(20.0 \% ; 20.0 \%)$, and tropical two-wing flyingfish (Exocoetus volitans) $(12.0 \%$; $12.0 \%)$, respectively. According to the IRI, N. simplex (98.6\%) and Argonauta spp. (1.3\%) were the most important components in the diet (Table 5). The diversity index was 1.1 and the $B_{\mathrm{i}}$ was 0.003 . The trophic level of the stomach contents was estimated at 3.5 (SD 0.4). The ANOSIM test indicated a similar diet composition for the sexes $(R=0.007)$, size class $(R=0.094)$, months $(R=0.018)$, and capture times $(R=0.099)$.

\section{Diet composition in zone 2}

Yellowfin tuna prey items comprised 19 taxa (7 cephalopods, 1 crustaceans, and 11 fish species). Based on the $\% \mathrm{MN}$ and $\% \mathrm{MW}$ indices, the most important prey items were Argonauta spp. (33.1\%; 20.6\%), jumbo squid (27.9\%; 27.7\%), and Auxis spp. (9.5\%; 19.9\%), respectively. According to the IRI, jumbo squid (55.3\%), Argonauta spp. (30.4\%), and Auxis spp. (11.2\%) were the most important components in the diet (Table 6). The diversity index was 1.3 and the $B_{\mathrm{i}}$ was 0.1 . The trophic level of the stomach contents was estimated at 4.7 (SD 0.2). The ANOSIM test indicated a similar 

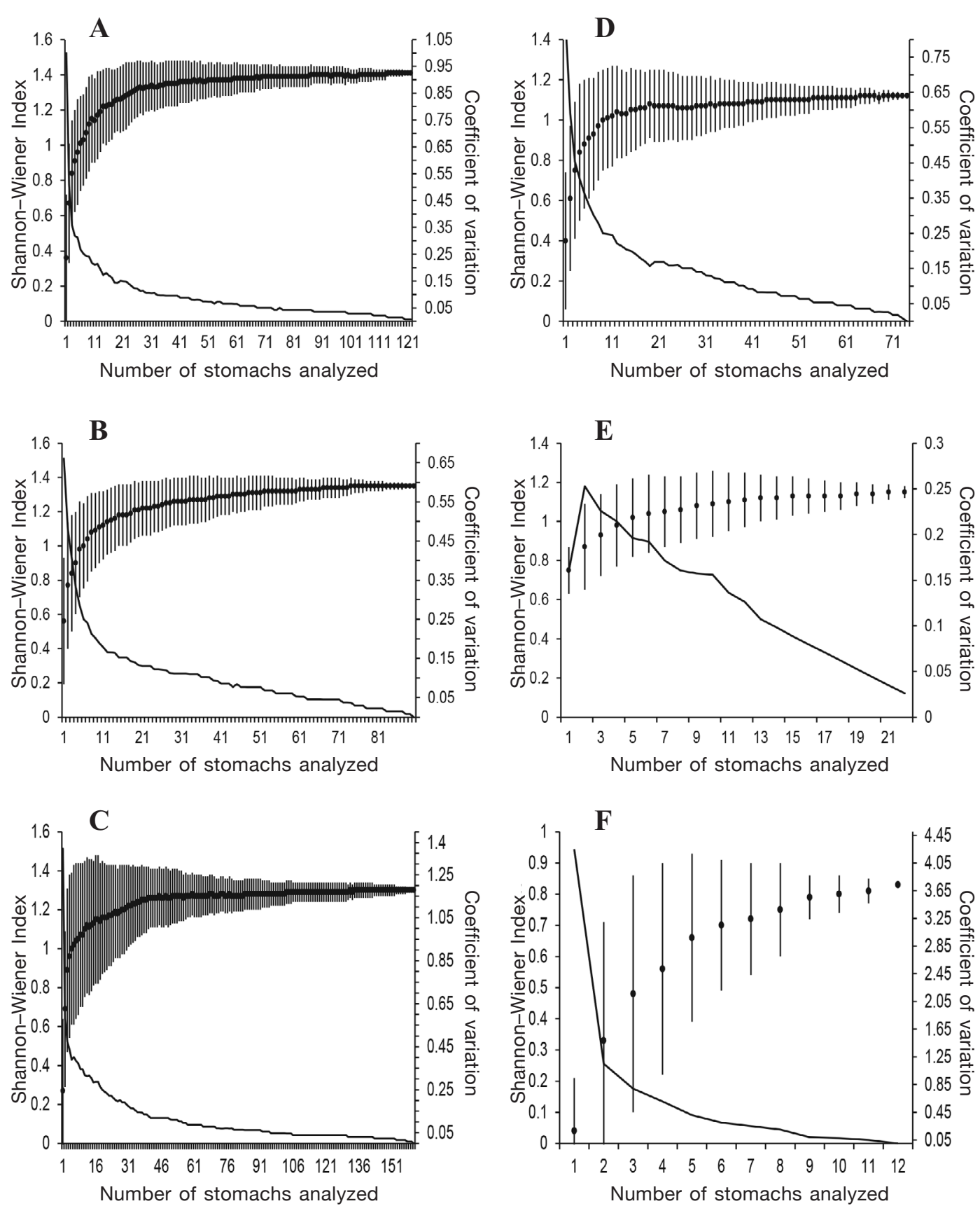

Figure 2

Randomized cumulative prey curves generated by using the Shannon-Wiener diversity index for yellowfin tuna (Thunnus albacares) in (A) zone 1, (B) zone 2, and (C) zone 3 and for skipjack tuna (Katsuwonus pelamis) in (D) zone 1, (E) zone 2, and (F) zone 3. The black lines indicate coefficients of variation. The vertical black lines indicate standard deviations.

diet composition among sexes $(R=0.017)$, size classes $(R=0.062)$, and capture times $(R=0.020)$, and diet differences among months of capture $(R=0.400, P=0.01$; January=Argonauta spp., Auxis spp., jumbo squid; February=jumbo squid; October=Auxis spp., smallwing flyingfish [Oxyporhamphus micropterus], Fig. 4).
Skipjack tuna prey items comprised 7 taxa (1 cephalopod and 6 fishes). Based on the $\% \mathrm{MN}$ and $\% \mathrm{MW}$ indices, the most important prey items were tropical twowing flyingfish $(79.5 \% ; 79.8 \%)$ and smallwing flyingfish $(4.4 \% ; 5.3 \%)$, respectively (Table 6$)$. According to the IRI, tropical two-wing flyingfish $(96.2 \%)$ and smallwing 


\section{Table 4}

Number of prey items present in the diet of yellowfin tuna (YT; Thunnus albacares) and skipjack tuna (ST; Katsuwonus pelamis) caught in 2005 in fishng zones 1-3 in the eastern tropical Pacific Ocean, by digestive state (DS), geographic zone, capture time (morning $[\mathrm{M}]$, afternoon $[\mathrm{A}]$, and evening $[\mathrm{E}]$ ) and category of prey species (fish [F], cephalopod [C], and crustacean $[\mathrm{Cr}]$ ). DS level $1=$ food includes recently consumed items; DS level 2 =food items with little to no skin remaining; 3 DS level=presence of fish skeletons; and DS level $4=$ presence of hard structures like fish otoliths, crustacean remains, and cephalopod beaks.

\begin{tabular}{|c|c|c|c|c|c|c|c|c|c|c|c|c|c|c|}
\hline \multirow[b]{2}{*}{$\begin{array}{l}\text { Capture } \\
\text { time }\end{array}$} & \multirow[b]{2}{*}{$\begin{array}{c}\text { Predator } \\
\text { species }\end{array}$} & \multirow[b]{2}{*}{$\begin{array}{c}\text { Prey } \\
\text { species }\end{array}$} & \multicolumn{4}{|c|}{ Zone 1} & \multicolumn{4}{|c|}{ Zone 2} & \multicolumn{4}{|c|}{ Zone 3} \\
\hline & & & DS 1 & DS 2 & DS 3 & DS 4 & DS 1 & DS 2 & DS 3 & DS 4 & DS 1 & DS 2 & DS 3 & DS 4 \\
\hline \multirow[t]{6}{*}{ M } & \multirow[t]{3}{*}{ YT } & $\mathrm{F}$ & 0 & 9 & 159 & 1 & 0 & 2 & 2 & 0 & 0 & 6 & 103 & 16 \\
\hline & & $\mathrm{C}$ & 0 & 0 & 0 & 3 & 0 & 0 & 1 & 79 & 0 & 29 & 21 & 235 \\
\hline & & $\mathrm{Cr}$ & 2 & 2 & 0 & 0 & 0 & 0 & 0 & 0 & 35 & 637 & 563 & 0 \\
\hline & \multirow[t]{3}{*}{$\mathrm{ST}$} & $\mathrm{F}$ & 0 & 0 & 17 & 1 & 0 & 0 & 0 & 0 & 0 & 0 & 0 & 0 \\
\hline & & $\mathrm{C}$ & 0 & 0 & 0 & 1 & 0 & 0 & 0 & 0 & 0 & 0 & 0 & 0 \\
\hline & & Cr. & 0 & 4744 & 1196 & 0 & 0 & 0 & 0 & 0 & 0 & 0 & 0 & 0 \\
\hline \multirow[t]{6}{*}{$\mathrm{A}$} & \multirow[t]{3}{*}{$\mathrm{YT}$} & $\mathrm{F}$ & 0 & 86 & 423 & 0 & 0 & 1 & 9 & 30 & 0 & 0 & 36 & 0 \\
\hline & & $\mathrm{C}$ & 56 & 175 & 102 & 384 & 0 & 0 & 17 & 475 & 0 & 1 & 0 & 38 \\
\hline & & $\mathrm{Cr}$ & 218 & 1498 & 329 & 0 & 0 & 0 & 0 & 1 & 0 & 0 & 0 & 0 \\
\hline & \multirow[t]{3}{*}{ ST } & $\mathrm{F}$ & 0 & 0 & 7 & 0 & 0 & 0 & 26 & 3 & 0 & 0 & 0 & 0 \\
\hline & & $\mathrm{C}$ & 0 & 0 & 0 & 5 & 0 & 0 & 0 & 1 & 0 & 0 & 0 & 0 \\
\hline & & $\mathrm{Cr}$ & 2227 & 32,251 & 2159 & 0 & 0 & 0 & 0 & 1 & 0 & 0 & 0 & 0 \\
\hline \multirow[t]{6}{*}{$\mathrm{E}$} & \multirow[t]{3}{*}{$\mathrm{YT}$} & $\mathrm{F}$ & 0 & 4 & 948 & 1 & 0 & 6 & 204 & 14 & 0 & 7 & 1229 & 2 \\
\hline & & $\mathrm{C}$ & 0 & 216 & 0 & 641 & 0 & 111 & 29 & 626 & 0 & 0 & 7 & 160 \\
\hline & & $\mathrm{Cr}$ & 66 & 545 & 362 & 1 & 0 & 0 & 1 & 0 & 0 & 26 & 268 & 0 \\
\hline & \multirow[t]{3}{*}{$\mathrm{ST}$} & $\mathrm{F}$ & 0 & 0 & 0 & 0 & 0 & 1 & 0 & 25 & 0 & 2 & 44 & 4 \\
\hline & & $\mathrm{C}$ & 0 & 0 & 0 & 3 & 0 & 0 & 0 & 0 & 0 & 2 & 0 & 0 \\
\hline & & $\mathrm{Cr}$ & 0 & 3628 & 120 & 0 & 0 & 0 & 0 & 0 & 0 & 0 & 0 & 0 \\
\hline
\end{tabular}

flyingfish $(2.49 \%)$ were the most important components in the diet. The diversity index was 1.1 and the $B_{\mathrm{i}}$ was 0.1 . The trophic level of the stomach contents was estimated at 4.1 (SD 0.2). The ANOSIM test indicated a similar diet composition among sexes $(R=0.009)$, size classes $(R=0.020)$, months of capture $(R=0.007)$, and capture times $(R=0.120)$.

\section{Diet composition in zone 3}

Yellowfin tuna prey items comprised 23 taxa (8 cephalopods, 2 crustaceans and 13 fishes). The \%MN and $\% \mathrm{MW}$ indices indicated that the most important prey items were pelagic red crab (23.8\%; 25.6\%), Argonauta spp. (20.5\%; 13.3\%), and Panama lightfish (16.2\%; $17.1 \%$ ) respectively. According to the IRI, pelagic red crab (46.2\%), Panama lightfish (24.7\%), and Auxis spp. (17.4\%) were the most important components of the diet (Table 7). The diversity index was 1.3 and the $B_{i}$ was 0.1 . The trophic level of the stomach contents was estimated at 4.5 (SD 0.4). The ANOSIM test indicated a similar diet composition among sexes $(R=0.014)$, size classes $(\mathrm{R}=0.060)$, months of capture $(R=0.120)$, and capture times $(R=0.067)$.

Skipjack tuna prey items comprised 3 taxa (1 cepha- lopod and 2 fish species). The $\% \mathrm{MN}$ and $\% \mathrm{MW}$ indices indicated that the most important prey items were tropical two-wing flyingfish $(66.7 \% ; 66.8 \%)$ and Panama lightfish $(29.2 \% ; 25.0 \%)$ respectively. According to the IRI, tropical two-wing flyingfish $(83.8 \%)$ and Panama lightfish $(15.8 \%)$ were the most important components of the diet (Table 7). The diversity index was 0.8 and the $B_{\mathrm{i}}$ was 0.6 . The trophic level of the stomach contents was estimated at 4.1 (SD 0.3). The ANOSIM test indicated a similar diet composition for sexes $(R=0.098)$ and months of capture $(R=0.180)$, and differences between size classes $(R=0.212, P=0.04$; small individuals primarily consumed tropical two-wing flyingfish, and large individuals primarily consumed Panama lightfish and tropical two-wing flyingfish) (Fig. 5). The ANOSIM test for capture times could not be performed because of the presence of empty stomachs.

\section{Comparisons of diets}

The ANOSIM showed differences in diet composition between yellowfin tuna and skipjack tuna in zone 1 ( $R=0.40, P=0.01)$, zone $2(R=0.60, P=0.01)$, and zone 3 $(R=0.25, P=0.01)$. A SIMPER analysis indicated changes in the contribution of each prey species between 
Table 5

Summary of food categories in stomachs of yellowfin tuna (Thunnus albacares) and skipjack tuna (Katsuwonus pelamis) caught in 2005 in zone 1 of the eastern tropical Pacific Ocean, expressed as percentages of the mean proportion by number $(\% \mathrm{MN})$, mean proportion by weight $(\% \mathrm{MW})$, frequency of occurrence $(\% \mathrm{FO})$, and relative importance index $(\% \mathrm{IRI})$. $\mathrm{x}=\mathrm{not}$ present in the diet; $\mathrm{SWC}=$ stomachs with content; $\mathrm{TN}=$ total number of prey examined; TW=total weight (in grams) of prey examined.

\begin{tabular}{|c|c|c|c|c|c|c|c|c|c|c|c|c|c|}
\hline \multirow[b]{2}{*}{ Prey item } & & \multicolumn{6}{|c|}{$\begin{array}{l}\text { Thunnus albacares } \\
\quad(\mathrm{SWC}=124)\end{array}$} & \multicolumn{6}{|c|}{$\begin{array}{l}\text { Katsuwonus pelamis } \\
\quad(\mathrm{SWC}=75)\end{array}$} \\
\hline & & $\mathrm{TN}$ & $\% \mathrm{MN}$ & TW & $\% \mathrm{MW}$ & $\% \mathrm{FO}$ & $\% \mathrm{IRI}$ & $\mathrm{TN}$ & $\% \mathrm{MN}$ & $\mathrm{TW}$ & $\% \mathrm{MW}$ & $\% \mathrm{FO}$ & $\%$ IRI \\
\hline \multicolumn{14}{|l|}{ Cephalopoda } \\
\hline Teuthoidea & & 6 & 0.93 & 26.0 & 1.10 & 1.62 & 0.01 & $\mathrm{x}$ & $\mathrm{x}$ & $\mathrm{x}$ & $\mathrm{x}$ & $\mathrm{x}$ & $\mathrm{x}$ \\
\hline Loliginidae & $\begin{array}{l}\text { Lolliguncula (Loliolopsis) } \\
\text { diomedeae }\end{array}$ & 213 & 3.54 & 702.8 & 4.08 & 4.87 & 2.61 & $\mathrm{x}$ & $\mathrm{x}$ & $\mathrm{x}$ & $\mathrm{x}$ & $\mathrm{x}$ & $\mathrm{x}$ \\
\hline \multirow[t]{2}{*}{ Ommastrephidae } & Dosidicus gigas & 1139 & 20.66 & 1122.9 & 16.59 & 54.47 & 28.26 & 8 & 6.66 & 0.1 & 6.66 & 6.66 & 0.01 \\
\hline & Sthenoteuthis oualaniensis & 2 & 0.15 & 0.1 & 0.01 & 1.62 & 0.01 & $\mathrm{x}$ & $\mathrm{x}$ & $\mathrm{x}$ & $\mathrm{x}$ & $\mathrm{x}$ & $\mathrm{x}$ \\
\hline Thysanoteuthidae & Thysanoteuthis rhombus & 3 & 0.14 & 0.1 & 0.01 & 2.43 & 0.01 & $\mathrm{x}$ & $\mathrm{x}$ & $\mathrm{x}$ & $\mathrm{x}$ & $\mathrm{x}$ & $\mathrm{x}$ \\
\hline Mastigoteuthidae & Mastigoteuthis dentata & 4 & 0.20 & 0.1 & 0.01 & 2.43 & 0.01 & $\mathrm{x}$ & $\mathrm{x}$ & $\mathrm{x}$ & $\mathrm{x}$ & $\mathrm{x}$ & $\mathrm{x}$ \\
\hline \multicolumn{14}{|c|}{ Octopoda } \\
\hline Bolitaenidae & Japetella diaphana & 15 & 0.65 & 0.5 & 0.01 & 8.13 & 0.02 & $\mathrm{x}$ & $\mathrm{x}$ & $\mathrm{x}$ & $\mathrm{x}$ & $\mathrm{x}$ & $\mathrm{x}$ \\
\hline Argonautidae & Argonauta spp. & 186 & 3.67 & 18.93 & 0.09 & 24.39 & 1.00 & 1 & 1.33 & 0.1 & 1.33 & 1.33 & 0.01 \\
\hline Octopodidae & Octopus rubescens & 9 & 0.51 & 0.1 & 0.01 & 5.69 & 0.01 & $\mathrm{x}$ & $\mathrm{x}$ & $\mathrm{x}$ & $\mathrm{x}$ & $\mathrm{x}$ & $\mathrm{x}$ \\
\hline \multicolumn{14}{|l|}{ Crustacea } \\
\hline Euphausiidae & Nyctiphanes simplex & $\mathrm{x}$ & $\mathrm{x}$ & $\mathrm{x}$ & $\mathrm{x}$ & $\mathrm{x}$ & $\mathrm{x}$ & 46107 & 60.00 & 1750.4 & 60.00 & 60.00 & 98.60 \\
\hline Galatheidae & Pleuroncodes planipes & 3021 & 48.89 & 1692.3 & 54.20 & 59.35 & 61.12 & 248 & 20.00 & 133.3 & 20.00 & 20.00 & 1.29 \\
\hline Penaeidae & Penaeid shrimps & 2 & 0.01 & 1.1 & 0.01 & 0.81 & 0.01 & $\mathrm{x}$ & $\mathrm{x}$ & $\mathrm{x}$ & $\mathrm{x}$ & $\mathrm{x}$ & $\mathrm{x}$ \\
\hline \multicolumn{14}{|l|}{ Teleostei } \\
\hline Clupeidae & Harengula thrissina & 2 & 0.36 & 32.2 & 0.58 & 0.81 & 0.01 & $\mathrm{x}$ & $\mathrm{x}$ & $\mathrm{x}$ & $\mathrm{x}$ & $\mathrm{x}$ & $\mathrm{x}$ \\
\hline Phosichthyidae & Vinciguerria lucetia & 1363 & 3.70 & 410.7 & 3.90 & 13.82 & 5.11 & $\mathrm{x}$ & $\mathrm{x}$ & $\mathrm{x}$ & $\mathrm{x}$ & $\mathrm{x}$ & $\mathrm{x}$ \\
\hline \multirow[t]{2}{*}{ Exocoetidae } & Exocoetus spp. & 1 & 0.05 & 0.2 & 0.01 & 0.81 & 0.01 & $\mathrm{x}$ & $\mathrm{x}$ & $\mathrm{x}$ & $\mathrm{x}$ & $\mathrm{x}$ & $\mathrm{x}$ \\
\hline & Exocoetus volitans & $\mathrm{x}$ & $\mathrm{x}$ & $\mathrm{x}$ & $\mathrm{x}$ & $\mathrm{x}$ & $\mathrm{x}$ & 25 & 12.00 & 8.5 & 12.00 & 12.00 & 0.05 \\
\hline Carangidae & Seriola lalandi & 4 & 0.68 & 4.4 & 1.57 & 0.81 & 0.01 & $\mathrm{x}$ & $\mathrm{x}$ & $\mathrm{x}$ & $\mathrm{x}$ & $\mathrm{x}$ & $\mathrm{x}$ \\
\hline Coryphaenidae & Coryphaena spp. & 1 & 0.22 & 5.5 & 0.90 & 0.81 & 0.01 & $\mathrm{x}$ & $\mathrm{x}$ & $\mathrm{x}$ & $\mathrm{x}$ & $\mathrm{x}$ & $\mathrm{x}$ \\
\hline Chaetodontidae & Chaetodontids & 1 & 0.90 & 1.5 & 0.90 & 0.81 & 0.01 & $\mathrm{x}$ & $\mathrm{x}$ & $\mathrm{x}$ & $\mathrm{x}$ & $\mathrm{x}$ & $\mathrm{x}$ \\
\hline Scombridae & Auxis spp. & 4 & 1.14 & 30.3 & 1.20 & 3.25 & 0.03 & $\mathrm{x}$ & $\mathrm{x}$ & $\mathrm{x}$ & $\mathrm{x}$ & $\mathrm{x}$ & $\mathrm{x}$ \\
\hline Nomeidae & Cubiceps pauciradiatus & 253 & 13.36 & 338.4 & 13.94 & 0.81 & 1.81 & $\mathrm{x}$ & $\mathrm{x}$ & $\mathrm{x}$ & $\mathrm{x}$ & $\mathrm{x}$ & $\mathrm{x}$ \\
\hline
\end{tabular}

tuna species. The prey species that contributed most to dissimilarity were $N$. simplex $(53.7 \%)$ and pelagic red crab (21.9\%), in zone 1; Argonauta spp. (28.2\%), jumbo squid $(25.0 \%)$, and tropical two-wing flyingfish $(17.5 \%)$ in zone 2; Panama lightfish (24.5\%), tropical two-wing flyingfish $(22.1 \%)$, and pelagic red crab (18.2\%) in zone 3 (Table 8).

\section{Discussion}

\section{Digestive state of prey species}

The variation in the degree of digestion of yellowfin tuna prey is related to the type of prey (fishes, cephalopods, and crustaceans) and the time of day when feeding occurs (Magnuson, 1969; Brill, 1987; Galvan-Magaña, 1988). Olson and Boggs (1986) found that squid soft tissue passed through the stomach of yellowfin tuna in $5-10 \mathrm{~h}$, whereas the beak was the only cephalopod structure that persisted in the stomach because it is composed of digestion-resistant chitin. In contrast, the soft tissue of fishes passed through the stomach in about 6-18 h. Tunas are captured primarily during the day in the ETPO (Ortega-García et al., 1992). The low occurrence of prey found in digestive state 1 in the morning, but high in the afternoon and evening, indicated peak feeding activity in the afternoon and evening for both tuna species. This finding coincides with observations reported for different areas of the ETPO (Ortega-García et al., 1992; Román-Reyes, 2005). Because of the occurrence of prey in digestion state 2 and 3 (little fresh cephalopod tissue) in the afternoon and evening, we deduce that yellowfin and skipjack tunas actively feed on cephalopods at night and during early morning as they migrate to the surface (Olson and Boggs, 1986).

Also the presence of mesopelagic prey species in the diet of yellowfin and skipjack tunas may reflect the vertical migration habits of prey. Jumbo squid and 

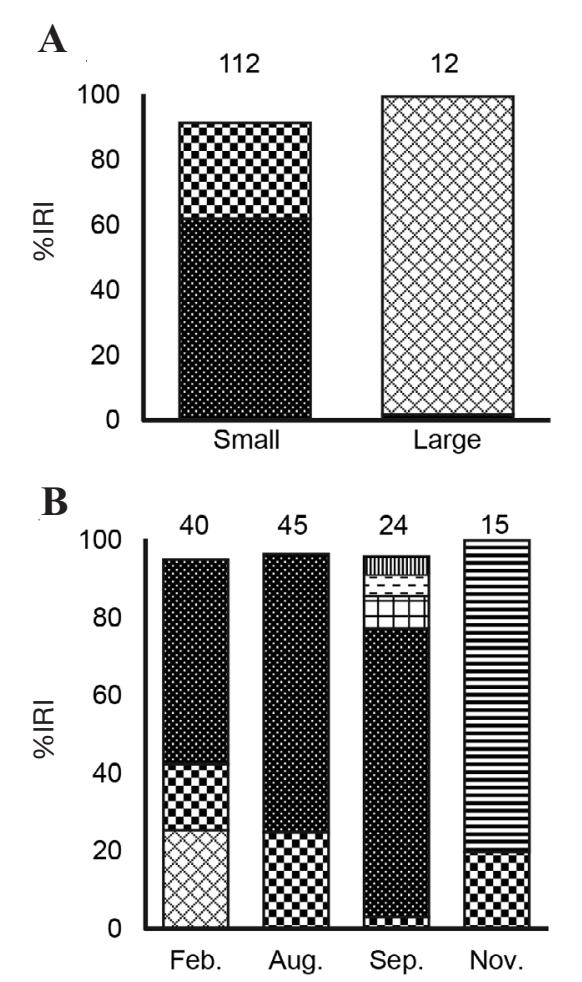

C
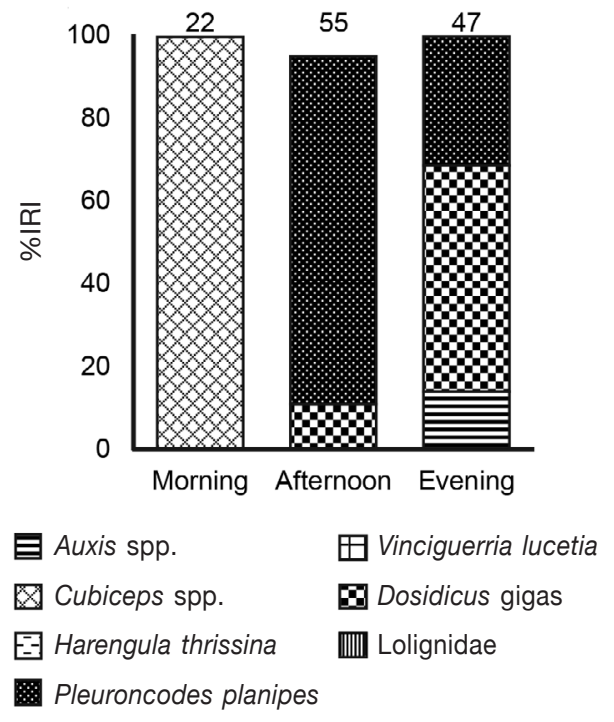

Figure 3

Variation in diet composition, determined with the relative importance index (\%IRI), in relation to (A) size class (small, 1-85 cm in fork length [FL], and large, $>85 \mathrm{~cm} \mathrm{FL}$ ), (B) months, and (C) capture time for yellowfin tuna (Thunnus albacares) caught in 2005 in zone 1 in the eastern tropical $\mathrm{Pa}$ cific Ocean. The numeral above each bar indicates the number of stomachs with contents.
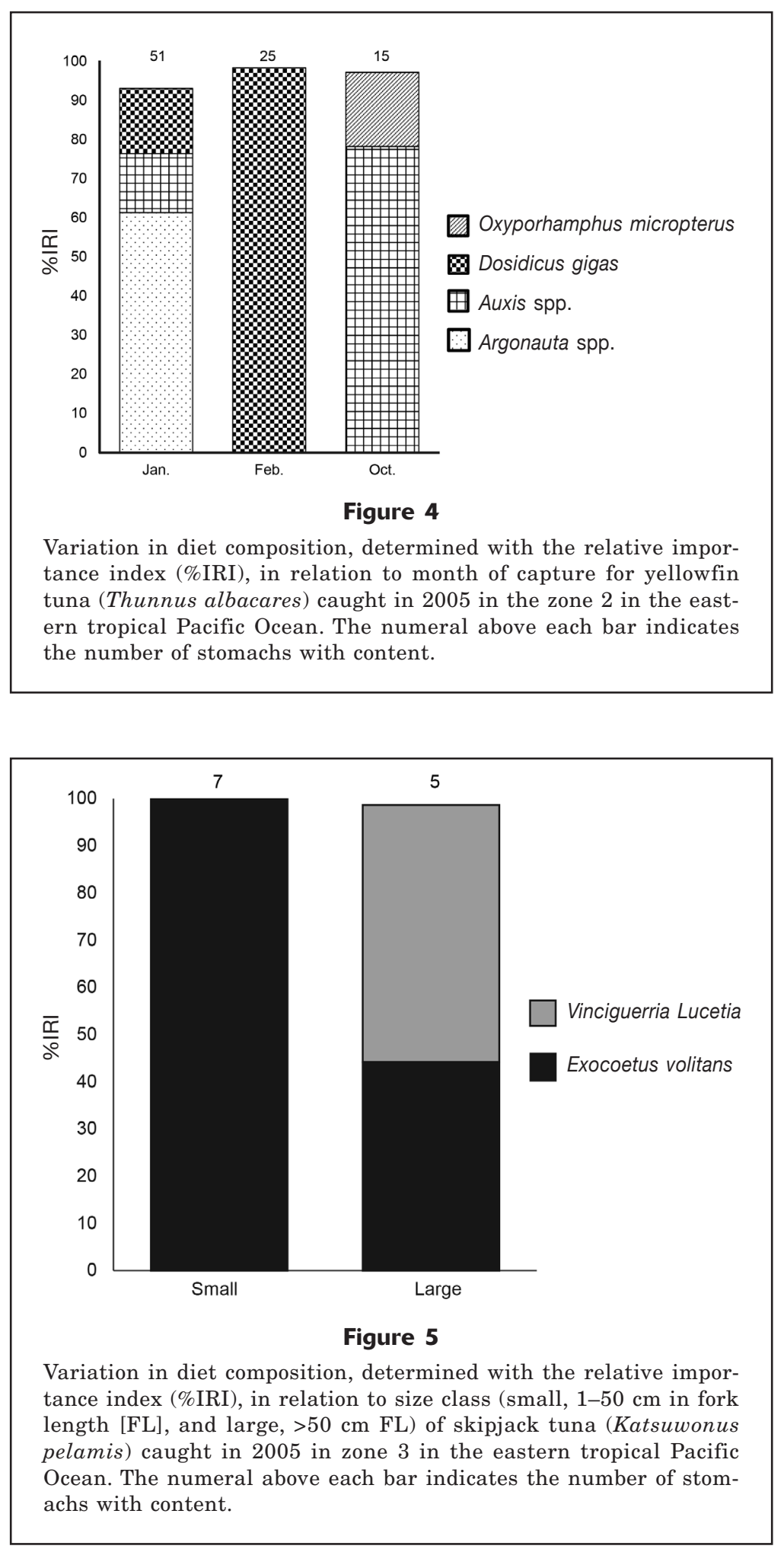

Panama lightfish make vertical migrations to the epipelagic area at night to feed (Olson and Boggs, 1986; Galván-Magaña, 1988). The presence of these prey species in the stomachs of yellowfin and skipjack tunas is likely the result of these movements into the epipelagic area where these tuna species forage. 


\section{Table 6}

Summary of food categories in stomachs of yellowfin tuna (Thunnus albacares) and skipjack tuna (Katsuwonus pelamis) caught in 2005 in zone 2 of the eastern tropical Pacific Ocean, expressed as percentages of the mean proportion by number $(\% \mathrm{MN})$, mean proportion by weight $(\% \mathrm{MW})$, frequency of occurrence $(\% \mathrm{FO})$, and relative importance index $(\% \mathrm{IRI}) . \mathrm{x}=\mathrm{not}$ present in the diet; $\mathrm{SWC}=$ stomachs with content; $\mathrm{TN}=$ total number of prey examined; TW=total weight (in grams) of prey examined.

\begin{tabular}{|c|c|c|c|c|c|c|c|c|c|c|c|c|c|}
\hline \multirow[b]{2}{*}{ Prey item } & & \multicolumn{6}{|c|}{$\begin{array}{c}\text { Thunnus albacares } \\
\quad(\mathrm{SWC}=91)\end{array}$} & \multicolumn{6}{|c|}{$\begin{array}{l}\text { Katsuwonus pelamis } \\
\quad(\mathrm{SWC}=22)\end{array}$} \\
\hline & & $\mathrm{TN}$ & $\% \mathrm{MN}$ & TW & $\% \mathrm{MW}$ & $\% \mathrm{FO}$ & $\%$ IRI & $\mathrm{TN}$ & $\% \mathrm{MN}$ & TW & $\% \mathrm{MW}$ & $\% \mathrm{FO}$ & $\%$ IRI \\
\hline \multicolumn{14}{|l|}{ Cephalopoda } \\
\hline Teuthoidea & & 1 & 8.98 & 0.1 & 2.89 & 12.63 & 0.01 & $\mathrm{x}$ & $\mathrm{x}$ & $\mathrm{x}$ & $\mathrm{x}$ & $\mathrm{x}$ & $\mathrm{x}$ \\
\hline Lepidoteuthidae & Pholidoteuthis boschmai & 3 & 0.41 & 0.1 & 0.35 & 3.15 & 0.01 & $\mathrm{x}$ & $\mathrm{x}$ & $\mathrm{x}$ & $\mathrm{x}$ & $\mathrm{x}$ & $\mathrm{x}$ \\
\hline Ommastrephidae & Dosidicus gigas & 612 & 27.95 & 2055.4 & 27.66 & 51.59 & 55.32 & 1 & 1.85 & 0.1 & 0.01 & 3.70 & 0.05 \\
\hline Thysanoteuthidae & Thysanoteuthis rhombus & 11 & 0.685 & 1.1 & 1.77 & 9.47 & 0.01 & $\mathrm{x}$ & $\mathrm{x}$ & $\mathrm{x}$ & $\mathrm{x}$ & $\mathrm{x}$ & $\mathrm{x}$ \\
\hline Mastigoteuthidae & Mastigoteuthis dentata & 20 & 0.87 & 0.1 & 0.97 & 8.42 & 0.12 & $\mathrm{x}$ & $\mathrm{x}$ & $\mathrm{x}$ & $\mathrm{x}$ & $\mathrm{x}$ & $\mathrm{x}$ \\
\hline \multicolumn{14}{|c|}{ Octopoda } \\
\hline Bolitaenidae & Japetella diaphana & 22 & 0.86 & 0.1 & 0.98 & 8.42 & 0.14 & $\mathrm{x}$ & $\mathrm{x}$ & $\mathrm{x}$ & $\mathrm{x}$ & $\mathrm{x}$ & $\mathrm{x}$ \\
\hline Argonautidae & Argonauta spp. & 595 & 33.11 & 8.6 & 20.64 & 66.31 & 30.42 & $\mathrm{x}$ & $\mathrm{x}$ & $\mathrm{x}$ & $\mathrm{x}$ & $\mathrm{x}$ & $\mathrm{x}$ \\
\hline \multicolumn{14}{|l|}{ Crustacea } \\
\hline Squillidae & Squillid mantis shrimps & 1 & 0.14 & 1 & 0.55 & 1.05 & 0.01 & 1 & 1.85 & 0.1 & 0.01 & 3.70 & 0.05 \\
\hline \multicolumn{14}{|l|}{ Teleostei } \\
\hline Clupeidae & Harengula thrissina & 1 & 0.26 & 11 & 0.10 & 1.05 & 0.01 & $\mathrm{x}$ & $\mathrm{x}$ & $\mathrm{x}$ & $\mathrm{x}$ & $\mathrm{x}$ & $\mathrm{x}$ \\
\hline Phosichthyidae & Vinciguerria lucetia & 160 & 6.39 & 55.9 & 8.47 & 8.42 & 1.17 & 1 & 3.70 & 0.2 & 3.70 & 3.70 & 0.06 \\
\hline Hemiramphidae & Oxyporhamphus micropterus & 21 & 4.19 & 75.3 & 2.59 & 10.52 & 0.40 & 4 & 4.44 & 59.5 & 5.31 & 11.11 & 2.49 \\
\hline \multirow[t]{5}{*}{ Exocoetidae } & Exocoetids & 2 & 0.05 & 30.6 & 1.12 & 2.10 & 0.02 & 1 & 1.85 & 2.5 & 3.70 & 3.70 & 0.08 \\
\hline & Exocoetus spp. & 3 & 0.79 & 34.8 & 0.27 & 1.05 & 0.01 & 4 & 4.93 & 21.0 & 3.80 & 7.40 & 0.89 \\
\hline & Hirundichthys spp & $\mathrm{x}$ & $\mathrm{x}$ & $\mathrm{x}$ & $\mathrm{x}$ & $\mathrm{x}$ & $\mathrm{x}$ & 1 & 1.85 & 13.0 & 3.70 & 3.70 & 0.19 \\
\hline & Exocoetus monocirrhus & 1 & 0.02 & 0.1 & 0.02 & 1.05 & 0.01 & $\mathrm{x}$ & $\mathrm{x}$ & $\mathrm{x}$ & $\mathrm{x}$ & $\mathrm{x}$ & $\mathrm{x}$ \\
\hline & Exocoetus volitans & 2 & 0.14 & 18.8 & 2.20 & 2.10 & 0.01 & 39 & 79.50 & 207.2 & 79.77 & 66.66 & 96.16 \\
\hline Carangidae & Jacks & 1 & 1.46 & 14.35 & 2.86 & 1.05 & 0.01 & $\mathrm{x}$ & $\mathrm{x}$ & $\mathrm{x}$ & $\mathrm{x}$ & $\mathrm{x}$ & $\mathrm{x}$ \\
\hline \multirow[t]{2}{*}{ Scombridae } & Scombrids & 1 & 4.20 & 13.0 & 6.67 & 1.05 & 0.01 & $\mathrm{x}$ & $\mathrm{x}$ & $\mathrm{x}$ & $\mathrm{x}$ & $\mathrm{x}$ & $\mathrm{x}$ \\
\hline & Auxis spp. & 34 & 9.50 & 1725.3 & 19.89 & 21.05 & 11.20 & $\mathrm{x}$ & $\mathrm{x}$ & $\mathrm{x}$ & $\mathrm{x}$ & $\mathrm{x}$ & $\mathrm{x}$ \\
\hline
\end{tabular}

\section{Diet composition by zone}

The diets of both tuna species are consistent with previous reports for the ETPO; however, we found fewer prey species in the fish stomachs than those of previous studies (Galván-Magaña, 1988; Román-Reyes, 2000). For yellowfin tuna, we recorded a total of 29 prey species, whereas Galván-Magaña (1988) reported a total of 53 prey species. For skipjack tuna, we recorded the occurrence of only 9 prey species, whereas Román-Reyes (2000) reported a total of 55 prey species in skipjack tuna stomachs. This variability in prey diversity may be associated with the number of stomachs analyzed; Galván-Magaña (1988) analyzed 1299 yellowfin tuna stomachs and Román-Reyes (2000) analyzed 611 stomachs of skipjack tuna. Despite the difference in the total number of prey species recorded, the most important prey have remained unchanged for both tuna species during the last 30 years in the ETPO. These include pelagic red crab, jumbo squid, and tropical two-wing flyingfish (Galván-Magaña, 1988; RománReyes, 2000; present study).
Crustaceans (primarily the pelagic red crab) were an important diet component by number, weight, and frequency of occurrence for both tuna species in zone 1 , but only for yellowfin tuna in zone 3 , which is in agreement with data reported by Alverson (1963). The pelagic red crab is a crustacean that has a pelagic juvenile phase, is present in high abundance at that phase, and is distributed vertically throughout the water column on the west coast of Baja California Sur, Mexico (zone 1). This region is influenced by the California Current during spring and summer. The abundance of the pelagic red crab in zone 3 may also be related to the intensity of the California Current (Lavin et al., 1997). Because the pelagic red crab is a passive swimmer, it can be transported to this zone by the California Current and therefore it becomes easy prey for several predators, including Panama hake (Merluccius angustimanus) (Balart and Castro-Aguirre, 1995), silky shark (Carcharhinus falciformis) (Cabrera-Chávez-Costa et al., 2010), and dolphinfish (Coryphaena hippurus) (Tripp-Valdez et al., 2010), in addition to yellowfin and skipjack tunas in both zones 1 and 3 . 


\section{Table 7}

Summary of food categories in stomachs of yellowfin tuna (Thunnus albacares) and skipjack tuna (Katsuwonus pelamis) caught in 2005 in Zone 3 of the eastern tropical Pacific Ocean, expressed as percentages of the mean proportion by number $(\% \mathrm{MN})$, mean proportion by weight (\%MW), frequency of occurrence $(\% \mathrm{FO})$, and relative importance index $(\% \mathrm{IRI})$. $\mathrm{x}=\mathrm{not}$ present in the diet; $\mathrm{SWC}=$ stomachs with content; $\mathrm{TN}=$ total number of prey examined; $\mathrm{TW}=$ total weight (in grams) of prey examined.

\begin{tabular}{|c|c|c|c|c|c|c|c|c|c|c|c|c|c|}
\hline \multirow[b]{2}{*}{ Prey item } & & \multicolumn{6}{|c|}{$\begin{array}{l}\text { Thunnus albacares } \\
\quad(\mathrm{SWC}=166)\end{array}$} & \multicolumn{6}{|c|}{$\begin{array}{l}\text { Katsuwonus pelamis } \\
\quad(\mathrm{SWC}=12)\end{array}$} \\
\hline & & $\mathrm{TN}$ & $\% \mathrm{MN}$ & TW & $\% \mathrm{MW}$ & $\% \mathrm{FO}$ & $\% \operatorname{IRI}$ & $\mathrm{TN}$ & $\% \mathrm{MN}$ & TW & $\% \mathrm{MW}$ & $\% \mathrm{FO}$ & $\%$ IRI \\
\hline \multicolumn{14}{|l|}{ Cephalopoda } \\
\hline Onychoteuthidae & Onychoteuthis banksii & 27 & 0.90 & 0.1 & 0.72 & 3.10 & 0.07 & $\mathrm{x}$ & $\mathrm{x}$ & $\mathrm{x}$ & $\mathrm{x}$ & $\mathrm{x}$ & $\mathrm{x}$ \\
\hline \multirow[t]{2}{*}{ Ommastrephidae } & Dosidicus gigas & 170 & 15.06 & 20.9 & 12.15 & 28.57 & 4.01 & 2 & 4.16 & 1.0 & 8.32 & 8.33 & 0.40 \\
\hline & Sthenoteuthis oualaniensis & 8 & 1.37 & 0.5 & 1.70 & 3.10 & 0.01 & $\mathrm{x}$ & $\mathrm{x}$ & $\mathrm{x}$ & $\mathrm{x}$ & $\mathrm{x}$ & $\mathrm{x}$ \\
\hline Thysanoteuthidae & Thysanoteuthis rhombus & 24 & 3.19 & 56.0 & 3.80 & 11.18 & 0.81 & $\mathrm{x}$ & $\mathrm{x}$ & $\mathrm{x}$ & $\mathrm{x}$ & $\mathrm{x}$ & $\mathrm{x}$ \\
\hline Mastigoteuthidae & Mastigoteuthis dentata & 9 & 0.72 & 0.1 & 1.26 & 5.59 & 0.03 & $\mathrm{x}$ & $\mathrm{x}$ & $\mathrm{x}$ & $\mathrm{x}$ & $\mathrm{x}$ & $\mathrm{x}$ \\
\hline \multicolumn{14}{|c|}{ Octopoda } \\
\hline Bolitaenidae & Japetella diaphana & 16 & 3.02 & 0.1 & 3.26 & 8.69 & 0.09 & $\mathrm{x}$ & $\mathrm{x}$ & $\mathrm{x}$ & $\mathrm{x}$ & $\mathrm{x}$ & $\mathrm{x}$ \\
\hline Argonautidae & Argonauta spp. & 235 & 20.52 & 3.6 & 13.31 & 39.13 & 6.59 & $\mathrm{x}$ & $\mathrm{x}$ & $\mathrm{x}$ & $\mathrm{x}$ & $\mathrm{x}$ & $\mathrm{x}$ \\
\hline Octopodidae & Octopus rubescens & 6 & 0.19 & 0.1 & 0.33 & 2.48 & 0.01 & $\mathrm{x}$ & $\mathrm{x}$ & $\mathrm{x}$ & $\mathrm{x}$ & $\mathrm{x}$ & $\mathrm{x}$ \\
\hline \multicolumn{14}{|l|}{ Crustacea } \\
\hline Galatheidae & Pleuroncodes planipes & 1523 & 23.85 & 654.3 & 25.64 & 26.70 & 46.16 & $\mathrm{x}$ & $\mathrm{x}$ & $\mathrm{x}$ & $\mathrm{x}$ & $\mathrm{x}$ & $\mathrm{x}$ \\
\hline Squillidae & Squillid mantis shrimps & 1 & 0.01 & 1.0 & 0.02 & 0.62 & 0.01 & $\mathrm{x}$ & $\mathrm{x}$ & $\mathrm{x}$ & $\mathrm{x}$ & $\mathrm{x}$ & $\mathrm{x}$ \\
\hline \multicolumn{14}{|l|}{ Teleostei } \\
\hline Phosichthyidae & Vinciguerria lucetia & 1330 & 16.18 & 435.5 & 17.14 & 18.01 & 24.71 & 25 & 29.16 & 3.1 & 25.00 & 33.33 & 15.78 \\
\hline \multirow[t]{3}{*}{ Exocoetidae } & Hirundichthys spp. & 1 & 0.62 & 0.1 & 0.62 & 0.62 & 0.01 & $\mathrm{x}$ & $\mathrm{x}$ & $\mathrm{x}$ & $\mathrm{x}$ & $\mathrm{x}$ & $\mathrm{x}$ \\
\hline & Exocoetus monocirrhus & 3 & 0.14 & 12.8 & 1.10 & 1.24 & 0.02 & $\mathrm{x}$ & $\mathrm{x}$ & $\mathrm{x}$ & $\mathrm{x}$ & $\mathrm{x}$ & $\mathrm{x}$ \\
\hline & Exocoetus volitans & $\mathrm{x}$ & $\mathrm{x}$ & $\mathrm{x}$ & $\mathrm{x}$ & $\mathrm{x}$ & $\mathrm{x}$ & 25 & 66.66 & 3.0 & 66.67 & 66.66 & 83.81 \\
\hline Carangidae & Jacks & 1 & 0.10 & 1.5 & 0.62 & 0.62 & 0.01 & $\mathrm{x}$ & $\mathrm{x}$ & $\mathrm{x}$ & $\mathrm{x}$ & $\mathrm{x}$ & $\mathrm{x}$ \\
\hline Coryphaenidae & Coryphaena hippurus & 2 & 0.06 & 0.5 & 0.05 & 0.62 & 0.01 & $\mathrm{x}$ & $\mathrm{x}$ & $\mathrm{x}$ & $\mathrm{x}$ & $\mathrm{x}$ & $\mathrm{x}$ \\
\hline Bramidae & Brama spp. & 2 & 0.64 & 2.8 & 0.82 & 1.24 & 0.01 & $\mathrm{x}$ & $\mathrm{x}$ & $\mathrm{x}$ & $\mathrm{x}$ & $\mathrm{x}$ & $\mathrm{x}$ \\
\hline Gempylidae & Gempylus spp. & 1 & 0.02 & 0.2 & 0.40 & 0.62 & 0.01 & $\mathrm{x}$ & $\mathrm{x}$ & $\mathrm{x}$ & $\mathrm{x}$ & $\mathrm{x}$ & $\mathrm{x}$ \\
\hline \multirow[t]{2}{*}{ Scombridae } & Scombrids & 1 & 0.10 & 0.1 & 0.60 & 0.62 & 0.01 & $\mathrm{x}$ & $\mathrm{x}$ & $\mathrm{x}$ & $\mathrm{x}$ & $\mathrm{x}$ & $\mathrm{x}$ \\
\hline & Auxis spp. & 40 & 10.66 & 1179.4 & 13.37 & 14.28 & 17.38 & $\mathrm{x}$ & $\mathrm{x}$ & $\mathrm{x}$ & $\mathrm{x}$ & $\mathrm{x}$ & $\mathrm{x}$ \\
\hline Nomeidae & Cubiceps pauciradiatus & 12 & 2.48 & 1.4 & 2.79 & 2.48 & 0.03 & $\mathrm{x}$ & $\mathrm{x}$ & $\mathrm{x}$ & $\mathrm{x}$ & $\mathrm{x}$ & $\mathrm{x}$ \\
\hline Balistidae & Balistes polylepis & 1 & 0.02 & 5.1 & 0.17 & 0.62 & 0.01 & $\mathrm{x}$ & $\mathrm{x}$ & $\mathrm{x}$ & $\mathrm{x}$ & $\mathrm{x}$ & $\mathrm{x}$ \\
\hline Ostraciidae & Lactoria diaphana & 1 & 0.05 & 0.5 & 0.61 & 0.62 & 0.01 & $\mathrm{x}$ & $\mathrm{x}$ & $\mathrm{x}$ & $\mathrm{x}$ & $\mathrm{x}$ & $\mathrm{x}$ \\
\hline
\end{tabular}

In zone 2, yellowfin tuna preyed primarily on cephalopods, followed by fishes and crustaceans. This is in agreement with previous reports for this species in the ETPO (Alverson, 1963; Galván-Magaña, 1988, 1999; Román-Reyes, 2000, 2005; Olson et al., 2014). The main cephalopod prey items in the trophic spectrum of yellowfin tuna were jumbo squid of the family Ommastrephidae and Argonauta spp. of the family Argonautidae. Members of the Ommastrephidae family undertake nightly vertical migrations toward the surface to feed (Markaida-Aburto, 2001), whereas members of the genus Argonauta are mostly epipelagic species that feed primarily during the day (Nesis, 1977). These cephalopods were also present in skipjack tuna stomachs, but were not important to their overall diet. In contrast, Nakamura (1965) reported that cephalopods were an important dietary component for skipjack tuna in the southern Pacific Ocean. Our data show, however, that skipjack tuna preyed primarily on fishes and yellowfin tuna preyed primar- ily on cephalopods in zone 2 , highlighting the dietary difference between these 2 predatory species within this geographic region.

In all 3 zones (1, 2, and 3$)$, the most important prey species of yellowfin and skipjack tunas were those that form aggregations, such as the pelagic red crab, jumbo squid, tropical two-wing flyingfish, and Panama lightfish; this finding confirms those of Galván-Magaña (1988) and Alverson (1963). The prey consumed by yellowfin tuna were mainly epipelagic species (pelagic red crab in zones 1 and 3, and Argonauta spp. in zone 2), whereas mesopelagic species (e.g., jumbo squid in zones 1 and 2, and Panama lightfish in zone 3) were consumed in smaller amounts. Watanabe (1958) reported that yellowfin tuna fed mainly in the epipelagic zone, which is a direct result of its distribution in the water column (Eslava et al., 2003). The main prey items found in skipjack tuna stomachs were epipelagic species (e.g., $N$. simplex, Auxis spp., smallwing flyingfish, and tropical two-wing flyingfish), confirming the information in 


\section{Table 8}

Results of the similarity of percentages analysis of taxa contributing to dissimilarity between yellowfin tuna (Thunnus albacares) and skipjack tuna (Katsuwonus pelamis) caught in 2005 in zones 1, 2, and 3 of the eastern tropical Pacific Ocean, including average number of individuals (Av. abund), dissimilarity with standard deviation ratios (Diss/SD), and percentage of contribution to the overall Bray-Curtis similarity between assemblages of the 2 tuna species (Contrib\%).

\begin{tabular}{|c|c|c|c|c|}
\hline & $\begin{array}{c}K . \text { pelamis } \\
\text { Av. abund }\end{array}$ & $\begin{array}{c}\text { T. albacares } \\
\text { Av. abund }\end{array}$ & Diss/SD & Contrib\% \\
\hline \multicolumn{5}{|l|}{ Zone 1} \\
\hline \multicolumn{5}{|l|}{ Average dissimilarity $=95.10$} \\
\hline \multicolumn{5}{|l|}{ Prey species } \\
\hline Nyctiphanes simplex & 614.7 & 0.00 & 1.14 & 53.66 \\
\hline Pleuroncodes planipes & 3.31 & 24.56 & 0.71 & 21.87 \\
\hline Dosidicus gigas & 0.11 & 9.26 & 0.48 & 9.04 \\
\hline Vinciguerria lucetia & 0.00 & 11.08 & 0.29 & 5.60 \\
\hline \multicolumn{5}{|l|}{ Zone 2} \\
\hline \multicolumn{5}{|l|}{ Average dissimilarity $=99.27$} \\
\hline \multicolumn{5}{|l|}{ Prey species } \\
\hline Argonauta spp. & 0.00 & 6.47 & 1.01 & 28.21 \\
\hline Dosidicus gigas & 0.04 & 6.65 & 0.77 & 24.97 \\
\hline Exocoetus volitans & 1.70 & 0.02 & 0.91 & 17.45 \\
\hline Vinciguerria lucetia & 0.00 & 1.74 & 0.30 & 5.65 \\
\hline \multicolumn{5}{|l|}{ Zone 3} \\
\hline \multicolumn{5}{|l|}{ Average dissimilarity $=97.4$} \\
\hline \multicolumn{5}{|l|}{ Prey species } \\
\hline Vinciguerria lucetia & 2.08 & 8.26 & 0.71 & 24.50 \\
\hline Exocoetus volitans & 2.08 & 0.00 & 0.84 & 22.12 \\
\hline Pleuroncodes planipes & 0.00 & 9.46 & 0.53 & 18.22 \\
\hline Argonauta spp. & 0.00 & 1.46 & 0.59 & 12.58 \\
\hline
\end{tabular}

Román-Reyes (2000), whereas mesopelagic species (e.g., Panama lightfish) were consumed in zone 3.

The presence of mesopelagic prey species in the diet of yellowfin and skipjack tunas may reflect the vertical migration of prey species. Jumbo squid and Panama lightfish make vertical migrations to the epipelagic area at night to feed (Olson and Boggs, 1986; GalvánMagaña, 1988).

\section{Comparison of diet between sexes and size classes}

For both tuna species in all zones in our study, there were no significant differences in feeding between the sexes (ANOSIM values close to 0). Nakamura (1965), for skipjack tuna, and Alverson (1963), for yellowfin tuna, reported high diet similarity for both sexes, suggesting that males and females frequented the same areas. Between size classes, however, our data show dietary differences: in zone 1 for yellowfin tuna and in zone 3 for skipjack tuna. Olson and Boggs (1986) reported that the yellowfin tuna trophic spectrum (diet) in the ETPO depends on predator size-a result that we found in our data as well. Trophic level values were 3.9 for smaller fish and 4.5 for larger fish.
Changes in diet related to size can be attributed to differences in the energy requirements at distinct ontogenetic stages in the development of a fish (Olson and Galván-Magaña, 2002; Graham et al., 2007). For example, stage-specific dietary differences have been reported for skipjack tuna in other areas of the Pacific Ocean (Nakamura, 1965; Ankenbrandt, 1985). Our report of juvenile skipjack tuna feeding mainly on fishes (e.g., zone 3) is in agreement with that of RománReyes (2000), although the prey species differed. The main prey species of skipjack tuna in our study was the tropical two-wing flying fish, whereas Román-Reyes (2000) found the main prey species to be the mesopelagic fish $V$. lucetia. For yellowfin tuna, our data show that the juveniles fed on small abundant prey, such as pelagic red crab in zone 1, whereas adult yellowfin tuna fed on cephalopods or, as reported by RománReyes (2000), on fishes.

Diet variation of yellowfin and skipjack tunas is most likely to be related to the spatiotemporal distribution of the predators, and to the prey availability in different areas of the ETPO rather than to strict ontogenetic changes in predator size. Alverson (1963) mentioned that yellowfin tuna juveniles were usually 
found in coastal areas where crustaceans are abundant, while adults were found in oceanic areas where cephalopods and fishes predominate. Thus, the high diet similarity between tuna of different sizes and the temporal (monthly, yearly) variation reported previously (Alverson, 1963; Nakamura, 1965; Román-Reyes, 2000) indicate that the consumption of distinct prey by organisms of different sizes may be more closely related to spatiotemporal segregation (oceanic in contrast with coastal segregation) of predators and prey than to size-related developmental shifts, such as a shift because of the added energy demands for reproduction.

\section{Diet breadth}

Values of $B_{\mathrm{i}}$ indicate that yellowfin and skipjack tunas are specialist predators; however, because the prey species were different in the 3 zones and form large aggregations (e.g., pelagic red crab and jumbo squid), these tunas can better be described as opportunistic predators, assuming that prey items are consumed in proportion to their abundance and availability in each zone. This conclusion is justified because tunas tend to feed often and on the most abundant prey (Olson and Boggs, 1986; Galván-Magaña, 1988). For example, in zones 1 and 3 , the yellowfin tuna diet was dominated by pelagic red crab, which is abundant in upwelling areas of subtropical zones, generating large quantities of food that span several trophic levels (Alverson, 1963; Blackburn, 1969; Galván-Magaña, 1988; CabreraChávez-Costa et al., 2010; Tripp-Valdez et al., 2010). In zone 2, yellowfin tuna consumed large quantities of jumbo squid, which is one of the main prey species in the ETPO. The jumbo squid lives in the mesopelagic zone but can also be found over the continental slope, mainly in upwelling areas rich in nutrients (Ehrhardt et al., 1986; Markaida-Aburto, 2001).

\section{Trophic levels}

Our calculations indicated that the prey of skipjack and yellowfin tunas have trophic level values between 3.5 and 4.1, and between 3.9 and 4.6, respectively. These estimates are consistent with trophic position estimates for the diet of yellowfin and skipjack tunas in the ETPO based on stomach contents and stable isotopes of nitrogen (Olson and Watters, 2003; Popp et al., 2007; Olson et al., 2010; Hunsicker et al., 2012). Interspecific comparison of trophic level shows that skipjack tuna feed lower in the food web than yellowfin tuna-a characteristic that is likely related to body size. Cortés (1999) mentioned that trophic levels of top predators increased with size, with larger predators having higher trophic levels than those of their smaller counterparts (Magnuson and Heitz, 1971). Also, several authors noted that trophic level may increase intraspecifically as fish grow (Cousins, 1980, Cohen et al., 1993) because they have access to different habitats (Graham et al., 2007). In addition, as predator size increases, prey capture efficiency also increases (Torres-Rojas et al., 2012). Our yellowfin tuna specimens were larger than our skipjack tuna specimens, and were thus able to capture a wider range of prey.

\section{Comparisons of diet}

The low diet similarity and interspecific differences in diet diversity and $B_{\mathrm{i}}$ for co-occurring yellowfin and skipjack tunas indicate that the association between these 2 species is not because they feed on the same prey in the ETPO. Although both tuna species are considered epipelagic, and they were caught together in the same sets, their primary prey were different in all 3 of the geographic zones examined. One explanation for this was offered by Giller (1984), who mentioned that subtle differences in size or morphological structures can lead to differences in the prey consumed and reduce competition and facilitate coexistence. In the case of yellowfin and skipjack tunas, diet differences may be related to differences 1) in the anatomy of the gill raker apparatus of the species (Ankenbrandt, 1985), and 2) in body size (Graham et al., 2007). For example, Magnuson and Heitz (1971) attributed the presence of euphausids (e.g., $N$. simplex) in the stomachs of skipjack tunas in the ETPO and their absence in the stomachs of yellowfin tuna (that consumed fish) to the small size of euphausids and to the smaller gaps between gill rakers in skipjack tuna compared with those in yellowfin tuna.

Body size and morphological differences between these 2 tuna species, as described above, are possible reasons for the observed differences in the prey consumed that likely reduce competition and facilitate coexistence. Therefore, an alternative hypothesis to explain the occurrence of mixed schools is that these 2 tuna species accompany each other to protect themselves from predators, as has been suggested for dolphins and tunas (Scott and Cattanach, 1998); however, more studies on this issue should be carried out in order to clarify this unique behavior.

\section{Acknowledgments}

The authors thank the following organizations for academic and financial support: Consejo Nacional de Ciencia y Tecnología, Inter-American Tropical Tuna Commission, Instituto Politécnico Nacional (IPN), Instituto de Ecología, Pesquerías y Oceanografía del Golfo de México, Universidad Autónoma de Campeche, Programa Integral de Fortalecimiento Institucional, Estímulos al Desempeño de los Investigadores, and IPN Comisión de Operación y Fomento de Actividades Académicas.

\section{Literature cited}

Allen, G. R., and D. R. Robertson.

1994. Fishes of the tropical eastern Pacific, 332 p. Univ. Hawaii Press, Honolulu, HI. 
Alverson, F.

1963. The food of yellowfin and skipjack tunas in the eastern tropical Pacific Ocean. Inter-Am. Trop. Tuna Comm., Bull. 7:295-396.

Ankenbrandt, L.

1985. Food habits of bait-caught skipjack tuna, Katsuwonus pelamis, from the southwestern Atlantic Ocean. Fish. Bull. 83:379-386.

Balart, E. F., and J. L. Castro-Aguirre.

1995. Estimación del impacto de la depredación de merluza sobre la langostilla. In La langostilla: biología, ecología y aprovechamiento (D. Aurioles-Gamboa and E. F. Balart, eds.), p. 139-162. Centro de Investigaciones Biológicas del Noroeste, La Paz, México.

Blackburn, M.

1969. Condition related to upwelling which determine distribution of tropical tunas off western Baja California. Fish. Bull. 68:147-176.

Brill, R. W.

1987. On the standard metabolic rate of tropical tunas, including the effect of body size and acute temperature change. Fish. Bull. 85:25-35.

Brusca, R. C.

1980. Common intertidal invertebrates of the Gulf of California, $2^{\text {nd }}$ ed., 513 p. Univ. Arizona Press, Tucson, AZ.

Cabrera-Chávez-Costa, A. A., F. Galván-Magaña, and O. Escobar-Sánchez.

2010. Food habits of the silky shark Carcharhinus falciformis (Muller and Henle, 1839) of the western coast of Baja California Sur, Mexico. J. Appl. Ichthyol. 26:499 503. Article

Chipps, S. R., and J. E. Garvey.

2007. Assessment of diets and feeding patterns. In Analysis and interpretation of freshwater fisheries data (C. S. Guy and M. L. Brown, eds.), p. 473-513. Am. Fish. Soc., Bethesda, MD.

Christensen, V., and D. Pauly.

1992. ECOPATH II-a software for balancing steady-state ecosystem models and calculating network characteristics. Ecol. Model. 61:169-185. Article

Clarke, M. R. (ed.).

1986. A handbook for the identification of cephalopod beaks, 273 p. Clarendon Press, Oxford, UK.

Clarke, K. R., and R. M. Warwick.

2001. Change in marine communities: an approach to statistical analysis and interpretation, $2^{\text {nd }}$ ed., $161 \mathrm{p}$. PRIMER-E Ltd., Plymouth, UK.

Clothier, C. R.

1950. A key to some Southern California fishes based on vertebral characters. Calif. Dep. Fish Game, Fish Bull. $79,80 \mathrm{p}$.

Cohen J. E., S. L. Pimm, P. Yodzis, and J. Saldaña.

1993. Body sizes of animal predators and animal prey in food webs. J. Anim. Ecol. 62:67-78.

Colwell, R. K.

2006. EstimateS: statistical estimation of species richness and shared species from samples. Version 8. [Available from website.]

Cortés, E.

1997. A critical review of methods of studying fish feeding based on analysis of stomach contents: application to elasmobranch fishes. Can. J. Fish. Aquat. Sci. 54:726738. Article

1999. Standardized diet compositions and trophic levels of sharks. ICES J. Mar. Sci. 56:707-717. Article
Cousins, S. H.

1980. A trophic continuum derived from plant structure, animal size, and a detritus cascade. J. Theor. Biol. 82:607618. Article

Ehrhardt, N. M., N. A. Solís, P. S. Jaquemin, C. J. Ortiz, R. P. Ulloa, D. G. González, and B. F. García.

1986. Análisis de la biología y condiciones del stock del calamar gigante Dosidicus gigas en el Golfo de California, México, durante 1980. Cienc. Pesq. 5:63-76.

Eslava, N., L. W. González, and D. Gaertner.

2003. Asociación de la abundancia y la distribución vertical de atunes y peces de pico en el sureste del Mar Caribe. Rev. Biol. Trop. 51:213-219.

Ferry, L. A., and G. M. Cailliet.

1996. Sample size and data analysis: are we characterizing and comparing diet properly? In Gutshop '96: feeding ecology and nutrition in fish symposium proceedings; San Francisco, CA, 14-18 July (D. MacKinlay and K. Shearer, eds.), p 71-80. Am. Fish. Soc., Bethesda, MD.

Fiedler, P. C., V. Philbrick, and F. P. Chavez.

1991. Oceanic upwelling and productivity in the eastern tropical Pacific. Limnol. Oceanogr. 36:1834-1850. Article

Fischer, W., F. Krupp, W. Schneider, C. Sommer, K. E. Carpenter, and V. H. Niem.

1995. Guía FAO para la identificación de especies para los fines de la pesca. Pacífico centro-oriental. Vol. I. Plantas e invertebrados, 646 p. FAO, Rome.

Fitch, J. E., and R. L. Brownell Jr.

1968. Fish otholits in cetacean stomach and their importance in interpreting feeding habits. J. Fish. Res. Board Can. 25:2561-2574.

Galván-Magaña, F.

1988. Composición y análisis de la dieta del atún aleta amarilla Thunnus albacares en el Océano Pacífico mexicano durante el periodo 1984-1985. M.S. thesis, 86 p. Centro Interdisciplinario de Ciencias Marinas del Instituto Politécnico Nacional, La Paz, Baja California Sur, México.

1999. Relaciones tróficas interespecíficas de la comunidad de depredadores epipelágicos del Océano Pacífico oriental. Ph.D. thesis, 212 p. Centro de Investigación Científica y de Educación Superior, Ensenada, Baja California, México.

Giller, P. S.

1984. Community structure and the niche, 176 p. Chapman and Hall, London..

Graham, B. S., D. Grubbs, K. Holland, and B. N. Popp.

2007. A rapid ontogenetic shift in the diet of juvenile yellowfin tuna from Hawaii. Mar. Biol. 150:647658. Article

Griffiths, S. P., R. J. Olson, and G. M. Watters.

2013. Complex wasp-waist regulation of pelagic ecosystems in the Pacific Ocean. Rev. Fish Biol. Fish. 23:459475. Article

Hunsicker, M. E., R. J. Olson, T. E. Essington, M. N. Maunder, L. M. Duffy, and J. F. Kitchell.

2012. Potential for top-down control on tropical tunas based on size structure of predator-prey interactions. Mar. Ecol. Prog. Ser. 445:263-277. Article

Kessler, W. S.

2006. The circulation of the eastern tropical Pacific: a review. Prog. Oceanogr. 69:181-217. Article

Korsmeyer, K. E., and H. Dewar.

2001. Tuna metabolism and energetics. In Fish physiol- 
ogy: tuna physiology, ecology, and evolution (B. A. Block and G. Stevens, eds.), p. 35-78. Academic Press, San Diego, CA.

Krebs, C. J.

1999. Ecological methodology, 620 p. Addison Wesley Longman, Menlo Park, CA.

Labropoulou, M., and A. Eleftheriou.

1997. The foraging ecology of two pairs of congeneric demersal fish species: importance of morphological characteristics in prey selection. J. Fish Biol. 50:324340. Article

Lavin, M., A. Badan, and E. Beier.

1997. Hydrographic structure and water circulation of the Gulf of California: seasonal and inter-annual scales. In Contribution to the physical oceanography in Mexico (M. F. Lavin, ed.), p 141-171. Unión Geofísica Mexicana, Ensenada, Baja California, México.

Magnuson, J. J.

1969. Digestion and food consumption by skipjack tuna (Katsuwonus pelamis). Trans. Am. Fish. Soc. 98:379-392. Article

Magnuson, J. J., and J. G. Heitz.

1971. Gill raker apparatus and food selectivity among mackerels, tunas, and dolphins. Fish. Bull. 69:361-370.

Markaida-Aburto, U.

2001. Biología del calamar gigante Dosidicus gigas Orbigny, 1835 (Cephalopoda: Ommastrephidae) en el Golfo de California, México. Ph.D. thesis, 387 p. Centro de Investigación Científica y de Educación Superior, Ensenada, Baja California, Mexico.

Nakamura, E. L.

1965. Food and feeding habits of skipjack tuna (Katsuwonus pelamis) from the Marquesas and Tuamotu Islands. Trans. Am. Fish. Soc. 94:236-242. Article

Nesis, K. N.

1977. The biology of paper nautiluses, Argonauta boettgeri and A. hians (Cephalopoda: Octopoda), in the western Pacific and the seas of the East Indian Archipielago. [In Russian.] Zool. Zh. 56:1004-1014.

Nikolsky, G. V.

1963. The ecology of fishes, 352 p. Academic Press, London.

Olson, R. J., and C. H. Boggs.

1986. Apex predation by yellowfin tuna (Thunnus albacares): independent estimates from gastric evacuation and stomach contents, bioenergetics, and cesium concentrations. Can. J. Fish. Aquat. Sci. 43:1760-1775. Article

Olson, R. J., and F. Galván-Magaña.

2002. Food habits and consumption rates of common dolphinfish (Coryphaena hippurus) in the eastern Pacific Ocean. Fish. Bull. 100: 279-298.

Olson, R. J., and G. M. Watters.

2003. A model of the pelagic ecosystem in the eastern tropical Pacific Ocean. Inter-Am. Trop. Tuna Comm., Bull. 22:135-210.

Olson, R. J., B. N. Popp, B. S. Graham, G. A. López-Ibarra, F. Galván-Magaña, C. E. Lennert-Cody, N. Bocanegra-Castillo, N. J. Wallsgrove, E. Gier, V. Alatorre-Ramírez, et al.

2010. Food-web inferences of stable isotope spatial patterns in copepods and yellowfin tuna in the pelagic eastern Pacific Ocean. Prog. Oceanogr. 86:124-138. Article

Olson, R. J., L. M. Duffy, P. M. Kuhnert, F. Galván-Magaña, N. Bocanegra-Castillo, and V. Alatorre-Ramírez.

2014. Decadal diet shift in yellowfin tuna Thunnus albacares suggests broad-scale food web changes in the eastern tropical Pacific Ocean. Mar. Ecol. Prog. Ser. 497:157-178. Article

Ortega-García, S., F. Galván-Magaña, and J. Arvizu-Martínez. 1992. Actividad de la flota atunera Mexicana de cerco y el comportamiento alimenticio del atún aleta amarilla. Cienc. Mar. 18:139-149.

Pennington, J. T., K. L. Mahoney, V. S. Kuwahara, D. D. Kolber, R. Calienes, and F. P. Chavez.

2006. Primary production in the eastern tropical Pacific: a review. Prog. Oceanogr. 69:285-317. Article

Petit, M.

1991. Contribution de la tèlèdètection àerospatiale à l'èlaboration des bases de l'halieutique opèrationnelle: l'example des pecheries thonières tropicales de surface (aspect èvaluatif). Ph.D. thesis, 129 p. Univ. Paris Vl, Paris.

Picaut, J.

1985. Major dynamics affecting the eastern tropical Atlantic and Pacific Oceans. CalCOFI Rep. 26:41-50.

Pinkas, L., M. S. Oliphant, and I. L. K. Iverson.

1971. Food habits of albacore, bluefin tuna and bonito in California waters. Calif. Dep. Fish Game, Fish Bull. $152,105$.

Popp, B. N., B. S. Graham, R. J. Olson, C. C. S. Hannides, M. J. Lott, G. A. López-Ibarra, F. Galván-Magaña, and B. Fry. 2007. Insight into the trophic ecology of yellowfin tuna, Thunnus albacares, from compound-specific nitrogen isotope analysis of proteinaceous amino acids. In Stable isotopes as indicators of ecological change (T. E. Dawson and R. T. W. Siegwolf, eds.), p. 173-190. Academic Press, San Diego, CA.

Román-Reyes, J. C.

2000. Hábitos alimenticios del barrilete (Katsuwonus pelamis) capturado por la flota atunera Mexicana en el Océano Pacifico Oriental durante 1997. M.S. thesis, 120 p. Centro Interdisciplinario de Ciencias Marinas, La Paz, aja California Sur, México.

2005. Análisis del contenido estomacal y la razón de isótopos estables de carbono $\left(\delta^{13} \mathrm{C}\right)$ y nitrógeno $\left(\delta^{15} \mathrm{~N}\right)$ del atún aleta amarilla (Thunnus albacares), delfín manchado (Stenella attenuata) y delfín tornillo (Stenella longirostris) del Océano Pacífico oriental. PhD. thesis, 161p. Centro Interdisciplinario de Ciencias Marinas, La Paz, Baja California Sur, México.

Schaefer, K. M.

1998. Reproductive biology of yellowfin tuna (Thunnus albacares) in the eastern Pacific tuna. Inter-Am. Trop. Tuna Comm., Bull. 21:205-272.

Scott, M. D., and K. L. Cattanach.

1998. Diel patterns in aggregations of pelagic dolphins and tunas in the eastern Pacific. Mar. Mamm. Sci. 14:401428. Article

Scott, M. D., S. J. Chivers, R. J. Olson, P. C. Fiedler, and K. Holland.

2012. Pelagic predator associations: tuna and dolphins in the eastern tropical Pacific Ocean. Mar. Ecol. Prog. Ser. 458:283-302. Article

Steel, R. G. D., and J. H. Torrie.

1992. Bioestadística: principios y procedimientos, 622 p. Editorial Graf América, México.

Sund, P. N., M. Blackburn, and F. Williams.

1981. Tunas and their environment in the Pacific Ocean: a review. Oceanogr. Mar. Biol., Annu. Rev. 19:443-512.

Thomson, D. A., L. T. Findley, and A. N. Kerstitch.

2000. Reef fishes of the Sea of Cortez: the rocky-shore 
fishes of the Gulf of California, rev. ed., 353 p. Univ. Texas Press, Austin, TX.

Torres-Rojas, Y. E., A. Hernández-Herrera, S. Ortega-García, and M. Domeier.

2012. Stable isotope differences between blue marlin (Makaira nigricans) and striped marlin (Kajikia audax) in the southern Gulf of California, Mexico. Bull. Mar. Sci. 89:421-436. Article

Tripp-Valdez, A., F. Galván-Magaña, and S. Ortega-García. 2010. Feeding habits of dolphinfish (Coryphaena hippu- rus) in the southeastern Gulf of California, Mexico. J Appl. Ichthyol. 26:578-582. Article

Watanabe, $\mathrm{H}$.

1958. On the difference of the stomach contents of the yellowfin and bigeye tunas from the western equatorial Pacific. Rep. Nankai Reg. Fish. Res. Lab. 7:72-81.

Wolff, G. A.

1984. Identification and estimation of size from the beaks of 18 species of cephalopods from the Pacific Ocean. NOAA Tech. Rep. NMFS: 17, 50 p. 